\title{
The genus Orthomus Chaudoir, 1838 in the Iberian Peninsula and Morocco
}

\author{
Род Orthomus Chaudoir, 1838 на Иберийском полуострове \\ и в Марокко
}

\author{
José Serrano \\ Хосе Серрано
}

\begin{abstract}
Departamento de Zoología y Antropología Física, Facultad de Veterinaria. Campus de Espinardo, Universidad de Murcia. 30110 Murcia, Spain. E-mail: jserrano@um.es
\end{abstract}

KEY WORDS. Coleoptera, Carabidae, Pterostichini, Orthomus, taxonomy, species key, new status, Iberian Peninsula, Morocco.

КЛЮЧЕВЫЕ СЛОВА. Coleoptera, Carabidae, Pterostichini, Orthomus, таксономия, определитель, новый статус, Иберийский полуостров, Марокко.

ABSTRACT. Recent advances in the nomenclature and improvements in the description of morphological characters have made possible to better understand the variability of taxa of the genus Orthomus Chaudoir, 1838 , and to develop more accurate keys of Ibero Maghrebian species, whose information was to date scattered in different publications. A brief review of key morphological characters of these species based on the study of the collections of the University of Murcia and the National Museum of Natural Sciences of Madrid, has allowed to develop a comprehensive key to these taxa, what may help to check beetles of Orthomus. Likewise, the value of morphological and geographic characters is discussed on evolutionary grounds, as a basic knowledge for future phylogenetic studies of particular lineages.

RESUMEN. Los avances recientes en la solución de problemas de nomenclatura y las mejoras en la descripción de caracteres morfológicos han hecho posible una mejor comprensión de la variabilidad de las especies del género Orthomus Chaudoir, 1838, así como el desarrollo de claves más precisas de las especies ibero magrebinas, cuya información se hallaba dispersa en publicaciones diversas. Tras una revisión centrada en los caracteres de mayor validez taxonómica, efectuada en los individuos de las colecciones depositadas en la universidad de Murcia y el Museo Nacional de Ciencias Naturales (Madrid), se ha elaborado una clave de especies detallada, que puede ser útil para identificar los Orthomus. Asimismo, se ha discutido el valor de los caracteres morfológicos y geográficos en un contexto evolutivo, para obtener conclusiones básicas que faciliten futuras investigaciones filogenéticas de linajes particulares.
РЕЗЮМЕ. Последние достижения в номенклатуре и изучении морфологических признаков позволили лучше понять изменчивость таксонов рода Orthomus Chaudoir, 1838 и разработать более точные диагнозы иберо-магрибских видов, информация о которых до настоящего времени была разбросана по различным публикациям. Краткий обзор основных морфологических признаков этих видов, основанный на изучении коллекций Университета Мурсии и Национального музея естественных наук Мадрида, позволил разработать эффективный определитель этих таксонов. Ценность морфологических и географических признаков обсуждается с точки зрения эволюции, как основы знаний для будущих филогенетических исследований конкретных линий.

\section{Introduction}

The genus Orthomus Chaudoir, 1838 is a member of tribe Pterostichini Bonelli, 1810, subtribe Euchroina Chaudoir, 1874. In former times it was considered as a subgenus of the vast genus Pterostichus Bonelli, 1810, as did Fuente [1927] and Csiki [1930]. Jeannel [1942] considered it as having a genus rank, a criterion followed by French and Iberian taxonomists, as seen in Bonadona [1979], Coulon et al. [2011], Pupier and Coulon [2013], Mateu [1954], and the catalogues of Jeanne [1966, 1981], Zaballos and Jeanne [1994], J. Serrano [2003, 2013, 2020] and Aguiar and A. Serrano [2013]. Bousquet [2017] also kept on this criterion in the last Palearctic Catalogue, as did Wrase and Jeanne [2005] and Guéorguiev et al. [2014].

The genus is characterized at first sight by body shape and color. The rectangular pronotum is closely followed

How to cite this article: Serrano J. 2021. The genus Orthomus Chaudoir, 1838 in the Iberian Peninsula and Morocco // Russian Entomol. J. Vol.30. No.4. P.430-447. doi: 10.15298/rusentj.30.4.06 
by parallel elytra making up a compact body silhouette. This design is possibly related to keeping body water content in arid environments. Dorsal color varies between light red brown to dark brown or black (Fig. 1), that matches that of soil backgrounds proper of littoral and sublittoral areas of the Mediterranean, where most species live (captures in forest habitats are rare: O. tazekensis). According to Guéorguiev et al. [2014] key characters that may differentiate Orthomus from akin lineages are (i) tarsomeres of all legs glabrous dorsally; (ii) elytra with long parascutellar striae well-engraved and two discal setiferous punctures the first on stria $3 \mathrm{rd}$, the second in stria 2nd or interval 2-3, (iii) Pronotum subquadrate (sides straight or slightly narrowed towards hind angles), with anterior angles slightly to moderately prominent forward; (iv) abdominal sternites V-VII with transverse sulci complete and well-impressed. To these features it could be added body length moderate (7.0-12.5 $\mathrm{mm}$ ), 1-2 foveae in posterior basis of pronotum (the external one is often weakly impressed), an elongate median lobe of aedeagus with horizontal apical shaft, and a right paramere with olive shape.

Bousquet [2017], who was in charge of cataloging the tribe Pterostichini in the last Palearctic Catalogue, admitted six subgenera within the genus. He likely did not take into account the paper of Guéorguiev et al. [2014], that included an updated species checklist and valuable contributions to the taxonomy of Orthomus; this last genus is thought to include no other subgenera than the nominal one. In the following I shall follow the criteria of these last authors.

The genus includes 22 valid species and 29 taxa comprising subspecies [Guéorguiev et al., 2014]. Most species are located in the Iberian Peninsula, Morocco, Algeria and Tunisia. This distribution suggests a West Mediterranean origin of the lineage followed by dispersal events toward the Eastern Mediterranean and the Macaronesian archipelagoes.

One species shows a large distribution area encompassing almost the whole Mediterranean and the Canary Islands, O. berytensis (Reiche et Saulcy, 1855); two others are present in Iberia and Morocco; O. longior Chaudoir, 1873 is found in various countries of the Levant; the other taxa show a more restricted distribution to particular regions.

Modern approaches to the taxonomy of the genus started with Mateu in a series of papers [1951, 1954a, b, $1955,1957]$ including the whole group. The fauna from Morocco was treated by Antoine [1957] whereas valuable contributions were worked out by Jeanne during various decades [1974, 1981, 1988; 2005 with David Wrase]. The taxonomy of Orthomus and related taxa inhabiting the Canary Islands was treated by Machado [1992] in his brilliant monograph of Canarian ground beetles. A valuable approach based on the analysis of female genitalia was initiated by Giachino and Sciaky [1991], followed by Ortuño [1996] who studied the Iberian taxa. Pupier and Coulon [2013] extended this study to all Ibero-Maghrebian taxa what allowed to correct earlier conclusions attained by Pupier [2005] based only in the male genitalia. Further advances on Maghrebian taxa were derived from the work of Wrase and Jeanne [2005] whereas the Orthomus fauna of France was updated by Coulon et al. [2011]. Recent contributions have come from Guéorguiev et al. [2014] and Guéorguiev and Wrase [2016], that have solved complex problems. Chavanon et al. [2016] and Chavanon [2018] have provided valuable data on the Orthomus fauna of East Morocco. Thus, a key to Ibero-Moroccan taxa may now be developed to improve keys found in Fuente [1927] and Mateu [1954, 1957], and the comparative species analysis may help to understand the taxonomic and evolutionary meaning of studied characters.

\section{Material and Methods}

The studied material is deposited in the collections of the Departmento de Zoología y Antropología Física of the Universidad de Murcia (DZAFUM) and the Museo Nacional de Ciencias Naturales de Madrid (MNCN). The list of species and individuals is indicated in a final appendix. When individuals of a particular taxon were not available I have followed the published data, as it is the case of Orthomus starkei [Wrase, Jeanne, 2005].

Key characters were photographed with a Zeiss Stemi 508 stereomicroscope equipped with an Axiocam 208 camera. Male genitalia were dissected out from selected exemplars whereas data on the female genitalia were taken from the papers of Ortuño [1996] and Pupier and Coulon [2013]. However, I dissected out the unknown genitalia of $O$. berytensis, $O$. dimorphus and $O$. tazekensis rifensis, which are herewith illustrated.

A simplified procedure was followed to obtain the female genitalia: individuals were submerged in distilled water and heated into the microwave to ebullition, placed in a petri dish and dissected out: once tergites were removed the bursa copulatrix and spermatheca were identified in most cases and lately photographed and illustrated.

\section{Checklist of taxa of the genus Orthomus} included in this paper

O. abacoides Lucas, 1846: 46 (Oodes)

= trapezicollis Chaudoir, 1859: 117 (Feronia); = occidentalis Gautier des Cottes, 1870: 299; = modestus Reiche, 1871: 427 [rn] Algeria.

O. aubryi Jeanne, 1974: 68. Spain.

O. balearicus Piochard de la Brûlerie, 1868: 1xxx (Feronia) = szekessyi Jedlièka, 1956: 392 (Pterostichus)

Balearic Islands.

O. barbarus barbarus Dejean, 1828: 261 (Feronia) = hespericus Motschulsky, 1849: 73 syn. n.; = expansus Mateu, 1957: 98; = logronicus Mateu, 1957: 98 [unav.] Spain, France.

O. berytensis Reiche et Saulcy, 1855: 618 (Feronia) = proelongus Reiche et Saulcy, 1855: 619 (Feronia); = elongatus Chaudoir, 1859: 116 (Feronia); = ? rectangulus Fairmaire, 1859: li (Feronia); = haligena Wollaston, 1860: 87 (Pterostichus $)$ = ? varinii Gautier des Cottes, 1866: 178 (Feronia); = atlanticus Fairmaire, 1875: 543 (Feronia); = oceanicus Mateu, 1951: 283 [unav.]; = muluyensis Antoine, 1957: 205 
Sardinia, Sicily, Malta, Greece, Turkey, Cyprus, Syria, Lebanon, Israel, Egypt, Libya, Tunisia, Algeria, Morocco, Canary Islands

O. dimorphus antoinei Mateu, 1955: 70.

Morocco.

O. dimorphus dimorphus Antoine, 1933: 85.

Morocco.

O. formenterrae Breit, 1933: 67, stat.n. (Pterostichus). Balearic Islands

O. hispanicus Dejean, 1828: 260 (Feronia)

= quadrifoveolatus Chaudoir, 1859: 117 (Feronia). Portugal, Spain.

O. lacouri haroldi Pupier et Coulon, 2013: 221. Morocco.

O. lacouri kocheri Mateu, 1955: 68. Morocco.

O. lacouri lacouri Antoine, 1941: 38 (Platysma). Morocco, Algeria?

O. maroccanus Chaudoir, 1873: 108

= humeralis Antoine, 1957: 208 [unav.]

Morocco, Spain.

O. penibeticus Mateu et Colas, 1954: 53, stat.n. South Spain.

O. perezii Martínez-Sáez, 1873: 57 (Feronia). Central Spain.

O. planidorsis Fairmaire, 1872: 420 (Feronia). Spain, south France

O. starkei Wrase et Jeanne, 2005: 882.

Morocco (Rif Massif).

O. tazekensis rifensis Wrase et Jeanne, 2005: 885.

Morocco (Rif Massif).

O. tazekensis tazekensis Antoine, 1941: 411 (Platysma)

= scutellaris Antoine, 1941: 412 [unav.] Morocco (Middle Atlas).

O. velocissimus akbensis Mateu, 1955: 74

= transiens Mateu, 1957: 99 [unav.]; = malacensis Mateu, 1957: 99 [unav.]; = andalusiacus Mateu, 1957: 103; = malacensis Jeanne, 1981: 45

South Portugal, south Spain

O. velocissimus pardoi Mateu, 1957: 102 South Spain.

O. velocissimus velocissimus Waltl, 1835: 53 (Argutor). South Spain.

\section{Taxonomy}

Brief morphological description of taxa

Morphology and geographic distribution suggest that groups of taxa may represent a lineage with a common ancestor, and thus show a greater relatedness on key characters. Therefore, species are described within the groups indicated below.

\section{Group of Orthomus maroccanus}

According to Wrase and Jeanne [2005] the group is made up by Orthomus maroccanus, O. starkei and O. tazekensis. These species have eyes almost flat, scarcely protruding from head, long tempora, and a short metepisterna as long as wide, no or slightly narrowed posteriorly. The female genitalia of $O$. maroccanus [Ortuño, 1996] show a short spermathecal duct (Fig. 4 ) and a short and moderately dilated spermatheca toward apex; however, in $O$. tazekensis rifensis the spermatheca is notably dilated apicad (Fig. 9), as it is found in species of the akin group of $O$. hispanicus (Figs 15, 18). Median lobe of aedeagus is ventrally bent at various degrees and the apical shaft is triangular and almost equally narrowed at apex (Figs 3, 7, 10-11).

\section{Orthomus maroccanus Chaudoir, 1873}

Figs 1-4.

Dorsum dark piceous, appendages yellow reddish. Body length $8.0-9.8 \mathrm{~mm}$. Males shiny, females dull with isodiametric microsculpture strongly developed. Antennomeres pubescent from the second third of antennomere 4, sometimes with small distally hairs in antennomere 3 in addition to the long apical setae (Fig. 1).

Pronotum transverse with anterior angles moderately projecting forward (Fig. 1), side narrowed forward and only moderately narrowed backward, maximum width before middle, posterior angle obtuse without a small tooth. Basal foveae from almost smooth to clearly punctured, area between external impression and lateral margin (postangular field) notably convex.

Elytra moderately widened toward apex, slightly narrowed toward basis; striae fine, unpunctured, intervals slightly convex, interval 3 with two setigerous punctures adjoining stria 3; humerus well-marked with a small tooth; scutellar setigerous puncture present at base of a well-developed parascutellar stria.

Episterna and abdomen from distinctly punctured to almost smooth, punctures on ventrites sometimes connected by shallow longitudinal ridges. Metepisterna slightly longer than wide, L/W 1.1 (Fig. 2). Prosternal process not truncate. Mesotibia of males distinctly enlarged from middle to apex, metatibia slightly curved and weakly crenulate at internal margin of distal half.

Apical shaft of median lobe of the aedeagus large and equally narrowed to tip (Fig. 3), internal sac membranous and with longitudinal macrotrichia.

\section{Orthomus tazekensis (Antoine, 1941)}

Dorsum dark brown, appendages lighter, body length 7.3-9.7 $\mathrm{mm}$. Antennomeres pubescent from middle antennomere 4 , in rare cases with some fine, short setae at apex of antennomere 3 .

Pronotum transverse, anterior angle moderate or acutely projecting forward; maximum width before middle, side almost linearly narrowed to posterior angle, sometimes slightly sinuate. Inner basal fovea deep and linear, outer fovea frequently shallow, posterior basis with punctures in moderatelow density. Posterior basis somewhat depressed, including the postangular field.

Elytra moderately convex with fine and unpunctured fine striae, intervals slightly convex, interval 3 with 2 setigerous punctures adjoining stria 3 . Humerus well-marked with a moderate tooth projecting laterally. Parascutellar stria well-developed, without scutellar setigerous puncture (present in aberration "scutellaris" and O. tazekensis rifensis). Elytron microsculpture indistinct, elytra moderately shiny in males, isodiametric in females, that have dull elytra.

Prosternal process rounded. Meso- and metepisterna irregularly punctured, ventrites with rugose punctures. Mesotibia of males not dilated apically, metatibia almost straight, with crenulation at internal margin starting at about the beginning of apical half and consisting of about 8 tubercles. In $O$. tazekensis rifensis crenulation is rather weak.

Apical shaft of median lobe asymmetrical, more narrowed to tip in the left side, internal sac with some groups of middle-sized thorns, almost straight in lateral view.

This subspecies is found in forests of Middle Atlas, in the surroundings of Taza. 
Orthomus tazekensis rifensis Wrase et Jeanne, 2005 Figs 5-9.

Characters indicated above for the nominal subspecies are also found in this taxon (Fig. 5). Individuals of this subspecies differ from those of the nominal subspecies in having a scutellar pore puncture; ventrites show abundant punctures giving a rugose aspect (Fig. 6); crenulation of metatibia in males is more weakly developed (it consists of about 6 tubercles); the apical shaft of the median lobe of the aedeagus is shorter and almost evenly rounded apically (Fig. 7), and is almost straight in lateral view (Fig. 8); the open membranous sac extends toward basal bulb. Spermatheca notably dilated apically, perhaps due to full filling with spermatophora (Fig. 9). Its shape when empty couldn't be assessed.

This subspecies is found in Rif Mountains above the timber line [Wrase, Jeanne, 2005].
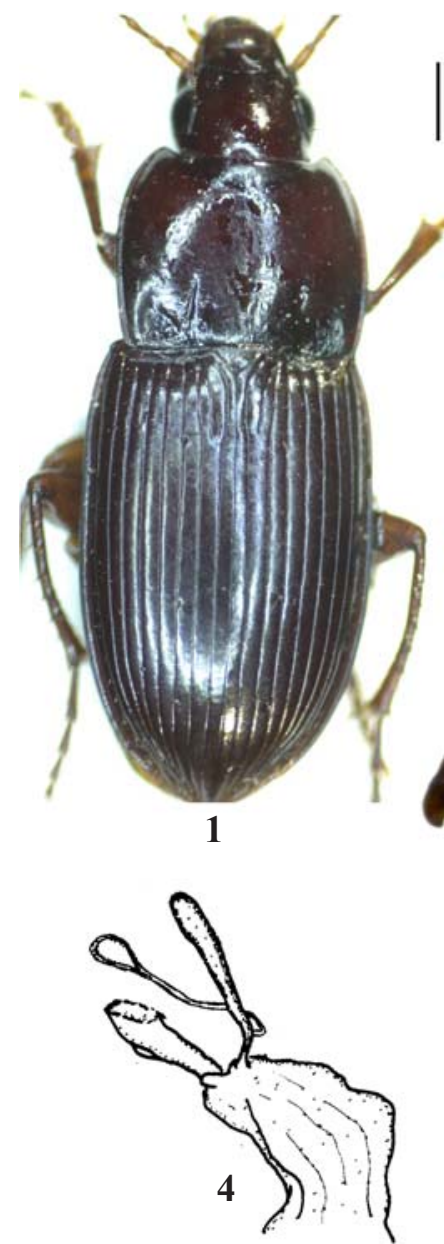

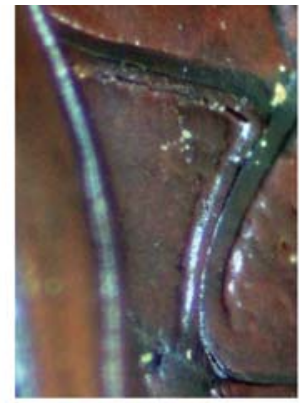

2

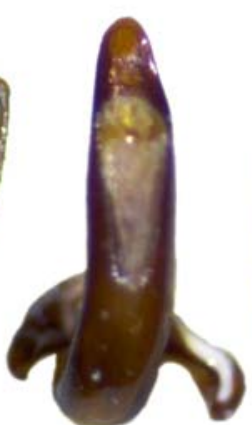

3

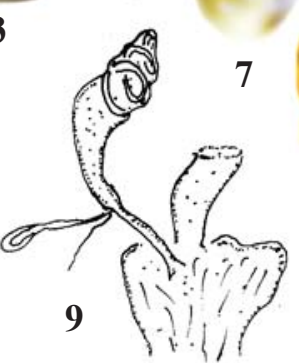

Orthomus starkei Wrase et Jeanne, 2005

Figs 10-11.

Dorsum from light to dark reddish brown; appendages somewhat lighter than body; body length 7.8-9.2 $\mathrm{mm}$. Eye fairly flat with long and flat tempora; antennae in both sexes with antennomere 9 reaching the pronotal base, pubescent from apical third of antennomere 3 (in addition to normal setae there are some fine short setae hardly visible).

Pronotum transverse, widest at about anterior third, anterior margin distinctly emarginate, anterior angle moderately projecting forward; posterior angle almost rectangular, side sinuate before it; posterior basis beaded from angle to the origin of internal basal impression, base slightly concave; disk convex; basal external fovea sparsely or not punctured, internal one deeper and with some distinct punctures.

Elytra long-oval, moderately convex, maximum width a little behind middle; striae fine and unpunctured, intervals

Figs 1-11. Orthomus spp: 1-4-O. maroccanus; $5-9-$ O. tazekensis rifensis; $10-11-O$. starkei; 1,5 - habitus; 2 - metepisterna; 6 - metepisterna and ventrites; 3, 7-8, 10-11 - median lobe of aedeagus; 4, 9 - genitalia of female; $1,5,3,7,11$ - dorsal view; 2, 6 right lateral view; 8, 10 - left lateral view; 1, 5-9 - Tidiquin Mnt., Rif, Morocco; 3 - San Roque, Cadiz, Spain; 4 - sierra del Cabrito, Tarifa, Cádiz, Spain; 11 — Sebt-des Beni Frassem, Rif, Morocco; 4, 9 — after Ortuño [1996]; 10-11 — after Wrase, Jeanne [2005]. Scale bars: $1.3 \mathrm{~mm}$ (Fig. 5); $1.4 \mathrm{~mm}$ (Fig. 1).

Рис. 1-11. Orthomus spp: 1-4-O. maroccanus; 5-9-O. tazekensis rifensis; $10-11-$ O. starkei; 1,5 - внешний вид; 2 - эпистерн заднегруди; 6- эпистерн заднегруди и вентриты; 3, 7-8, 10-11 - средняя доля эдеагуса; 4,9 - гениталии самки; $1,5,3,7,11$ сверху; 2, 6 -сбоку справа; 8, 10 -сбоку слева; 1, 5-9 - горы Тидиквин, Риф, Марокко; 3 - Сан-Роке, Кадис, Испания; 4 - сьерра дель-Кабрито, Тарифа, Кадис, Испания; 11 - Бени Фрассем, Риф, Марокко; 4, 9 - по Ortuco [1996]; 10-11 — по Wrase, Jeanne [2005]. Масштаб: 1,3 мм (Рис. 5); 1,4 мм (Рис. 1). 
slightly convex, interval 3 with two setigerous punctures adjoining stria 3; humerus well-marked with a small indistinct tooth; basal margin anteriorly concave, forming a weak acute angle (holotype) or an almost rectangular angle with lateral margin at the humerus. Setigerous pore present at base of a well-developed parascutellar stria. Microsculpture mesh pattern distinct, in males weakly transverse, in females isodiametric and slightly more stronger developed.

Prosternum (laterally), episterna and abdomen (laterally) with coarse and somewhat scattered irregular punctures, sometimes connected by shallow longitudinal ridges (last ventrites). Legs slender; mesotibia of males not dilated apically, metatibia not distinctly curved and without crenulation in internal side.

Male with median lobe of aedeagus strongly bent; apical shaft short and evenly rounded (Figs 10-11). Internal sac without thorns or teeth.

Known only from three localities situated not far from each other in the north-western region of Taza (Morocco), in agricultural lands free of forests, at elevations about 300 to $450 \mathrm{~m}$.

\section{Group of Orthomus hispanicus}

According to Jeanne [1974] this group is made up by $O$. hispanicus, $O$. perezii and $O$. aubryi. It is characterized by the presence of a short metepisterna, as wide as long (L/W 1.0) and narrowed backward, convex eyes and tempora moderately long. The female genitalia show a short $(O$. aubryi) or somewhat longer $(O$. hispanicus, $O$. perezii) spermathecal duct, and a progressively widened spermatheca, whereas the median lobe of the aedeagus is not notable bent ventrally and the apical shaft varies between equally narrowed apicad $(O$. perezii) and an asymmetrical shape (O. hispanicus).

Orthomus hispanicus (Dejean, 1828)

Figs $12-15$.

Dorsum brown dark, almost black, body length 7.0-9.0 $\mathrm{mm}$, males shiny with fine microreticulation, females somewhat dull with visible microreticulation. Eye convex, tempora oblique.

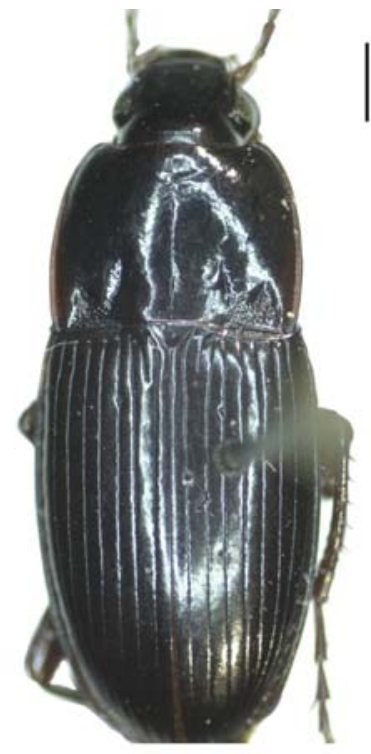

12

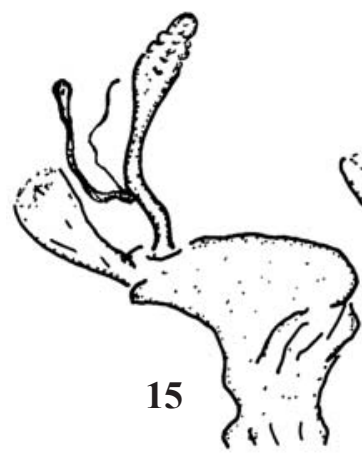

14

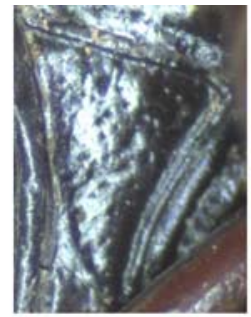

13
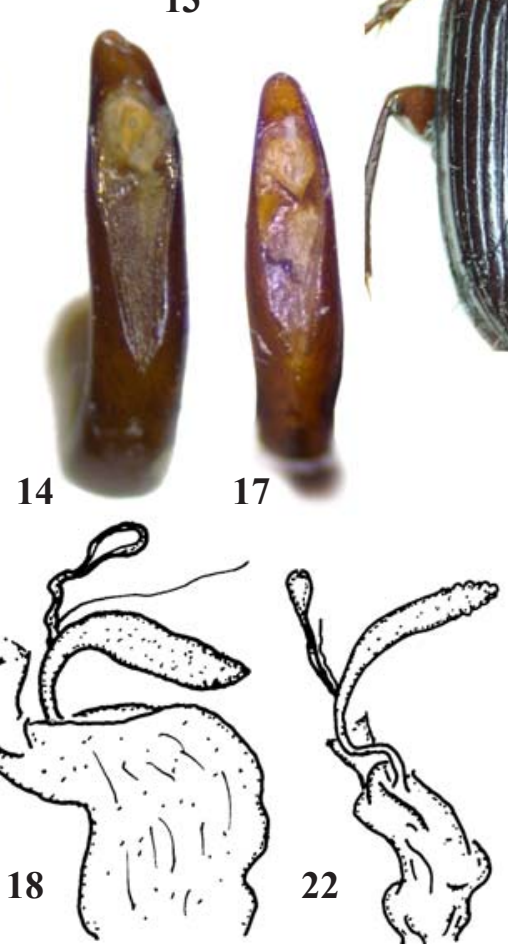

20

Figs 12-22. Orthomus spp, specimens from Spain: 12-15 - O. hispanicus; 16-18 - O. perezii; 19-22 - O. aubryi; 12, 16, 19habitus; 13 - metepisterna; 14, 17, 20-21 - median lobe of aedeagus; 15, 18, 22 - genitalia of female; 12, 14, 16-17, 19-20 - dorsal view; 13 - right lateral view; 21 - left lateral view; 14 - sierra de Larouco, Orense; 15 — Candelario, Salamanca; 17 - Campisábalos, Guadalajara; 18 - Valdefuentes de Sangusín, Salamanca; 19-21 - Moncayo Peak, Zaragoza; 22 — Linas de Broto, Huesca; 15, 18, 22 after Ortuño [1996]. Scale bars: $1.2 \mathrm{~mm}$ (Fig. 12); $1.3 \mathrm{~mm}$ (Fig. 16); $1.5 \mathrm{~mm}$ (Fig. 19).

Рис. 12-22. Orthomus spp, особи из Испании: 12-15-O. hispanicus; 16-18-O. perezii; 19-22 - O. аиbryi; 12, 16, 19-внешний вид; 13 - эпистерн заднегруди; 14, 17, 20-21 - средняя доля эдеагуса; 15, 18, 22 - гениталии самки; 12, 14, 16-17, 19-20 - сверху; 13 -сбоку справа; 21 -сбоку слева; 14 - Сьерра-де-Ларуко, Оренсе; 15 - Канделарио, Саламанка; 17 - Камписабалос, Гвадалахара; 18 - Вальдефуэнтес-де-Сангусин, Саламанка; 19-21 - пик Монкайо, Сарагоса; 22 - Линас-де-Брото, Уэска; 15, 18, 22 - по Ortuco [1996]. Масштаб: 1,2 мм (Рис. 12); 1,3 мм (Рис. 16); 1,5 мм (Рис. 19). 
Pronotum shape variable, either maximum width at apical 3/4 (more trapezoid) or at middle (more quadrate) (Fig. 12 ); posterior angle obtuse, slightly toothed, basis not emarginate. Foveae well marked and usually punctured.

Elytra moderately widened backward, side narrowed toward basis, humerus toothed, striae smooth or with traces of punctures, intervals flat in females and slightly convex in males; disk with distal seta on 3rd stria but it often varies as it is found in interval 3 , close to stria 2 or may be absent.

Prosternal process forming an obtuse ridge, rounded and emarginate on bottom, ventral segments punctured including metepisterna (Fig. 13), this as long as wide (L/W 1.0). Males with mesotibia somewhat enlarged apically and metatibia with traces of crenulation in apical internal side.

Median lobe of aedeagus slightly bent ventrally; apical shaft asymmetrical, more narrowed in left side and prolonged in the right side (Fig. 14); membranous sac devoid of teeth and only moderately open on dorsal view. Spermatheca dilated apically, spermathecal duct relatively short (Fig. 15)

Northern half of Portugal, Galicia, Cantabrian Mountains, Northern Sistema Ibérico, and Sistema Central from Serra da Estrela to sierra de Gredos.

\section{Orthomus perezii Martínez-Sáez, 1873} Figs $16-18$

Dorsum brown dark piceous, body size smaller than that of $O$. hispanicus, $6.0-7.5 \mathrm{~mm}$, males shiny, females mat. Eye less convex, tempora long.

Pronotum transverse, narrowed anteriad, maximum width at middle, slightly constricted backward (Fig. 16); posterior angle obtuse, no or at most, slightly toothed; basis not emarginate; foveae well marked and usually punctured, space between side and external fovea notably convex.

Elytra relatively short and oval, sides slightly widened backward, narrowed close to basis, basis forming at humerus a fold that doesn't protrude outside; parascutellar stria normally developed with a proximal hairy pore; intervals convex, striae smooth, second disk pore located variably: on the 2nd stria, in the interval between striae 2 and 3 , close to stria 3 .

Prosternal process rounded, ventral segments finely punctured and with rugose areas, metepisterna as long as wide (L/A 1.0). Male mesotibia somewhat enlarged apically, metatibia with crenulation moderately developed in apical internal side.

Apical shaft of median lobe of aedeagus well developed, as wide as long, evenly rounded to tip (Fig. 17); on lateral view almost straight; membranous sac open along the entire dorsal face. Spermatheca as described in O. hispanicus, with a notably dilated apical end (Fig. 1).

Sistema Central, Sistema Iberico (N and S), North Meseta, northern part of South Meseta.

\section{Orthomus aubryi Jeanne, 1974}

$$
\text { Figs 19-22. }
$$

Body length $8.5-10.0 \mathrm{~mm}$. Dorsum dark piceous, appendages reddish. Antennomeres pubescent from apical third of antennomere 3 to 11 , reaching the basis of elytra. Eye convex with long oblique tempora.

Pronotum with anterior angle moderately projecting forward, anterior basis almost regularly curved; maximum width before middle (Fig. 19), from here side is slightly arcuate and narrowed toward the obtuse posterior angle, that has a small protruding tooth. Basal foveae finely punctured, the internal deep, linear or curved, the external moderately impressed or almost faint.

Elytra relatively long (L/W 3.41), almost parallel, humeral tooth small or almost absent, striae smooth, intervals moderately convex, parascutellar stria somewhat short, distal dorsal pore adjoining stria 2 .

Episternae and first ventrites moderately punctured. Metepisternae as long as wide in the anterior margin (L/A 1.05). Male mesotibia slightly dilated apically, metatibia distally curved and with traces of crenulation in the distal inner side.

Apical shaft of median lobe of aedeagus elongate, somewhat more narrowed to the left (Fig. 20); on lateral view the median lobe of aedeagus is almost straight, the apex slightly curved upward (Fig. 21); membranous area (ostium) prolonged toward basis. The spermatheca (Fig. 22) show a similar shape to that described for $O$. hispanicus but the duct is longer. Differences in the length of the spermathecal duct led Ortuño [1996] to place $O$. aubryi near the $O$. planidorsis group. As $O$. aubryi might enter in contact with $O$. hispanicus and $O$. perezii in the west (Basque Mts., north Sistema Ibérico), and with $O$. planidorsis in the east (Central Pyrenees), the geographic distribution doesn't help in solving the affinities of the species. Molecular markers are needed to seed light into this question. Basque Mountains, Northern Sistema Ibérico (Moncayo Peak), central and western Pyrenees.

Groups of species with metepisterna longer that wider and narrowed posteriorly

Iberian taxa: Group of Orthomus barbarus

This group is made up by $O$. barbarus, O. velocissimus, $O$. formenterrae, and $O$. penibeticus. Males of this group show a distally dilated mesotibia and a metatibia variably crenulate in the distal half. The female genitalia show a long spermathecal duct followed by a long spermatheca [Ortuño, 1996; Pupier, Coulon, 2013]. Male genitalia are rather variable as the apical shaft of the median lobe of the aedeagus is triangular in some taxa, with rounded or acute tip, whereas it is truncate, with or without a tooth at tip. Taxa of this group are found below a hypothetical line that runs from the southwest of Iberia (Algarve and western Andalusia) to the eastern Pyrenees and south France, and also occupies the southernmost archipelago of the Balearic Islands, the Pitiusas (Ibiza and Formentera).

\section{Orthomus barbarus barbarus (Dejean, 1828)} Figs 23-27.

Dorsum between black and dark brown, males shiny, females less shiny or dull with isodiametric microreticulation. Body length $8.8-11.5 \mathrm{~mm}$. Legs black, antennae and tarsi dark red. Eye notably convex, tempora short.

Pronotum shape variable, most commonly showing a trapezoid contour more narrowed forward and side entirely curved, maximum width at middle or so (Fig. 23), anterior angle not markedly protruding forward; posterior angle toothed; inner basal fovea linear, outer fovea from rugose to almost erased, punctures of moderate size and at least abundant in inner fovea, postangular field moderately convex.

Elytra almost parallel, slightly narrowed toward basis; humeral tooth well developed; striae smooth or vaguely punctured, intervals almost flat; discal pores on 3rd stria; parascutellar stria normally developed with proximal setose pore.

Prosternal process rounded; ventral segments almost smooth, fine punctures are found on sides of last ventrites; metepisterna smooth, long and narrowed apicad, L/W 1.25) (Fig. 24).

Median lobe of aedeagus on lateral view with apical region curved upward; apical shaft on dorsal view rather variable between localities but predominating an elongate triangle evenly narrowed to tip and straight (Fig. 25), or deviated to right [see Mateu, 1957]. In lateral view the median lobe is somewhat ventrally bent (Fig. 26). The sper- 
mathecal duct is rather long, even longer than the spermatheca (Fig. 27)

The species is distributed in the Mediterranean coast from eastern Almeria to south France and also colonizes the South Meseta, Betic and Iberian chains and the River Ebro Basin.

\section{Orthomus formenterrae (Breit, 1933), stat.n.} Figs 28-31.

This species was described as Pterostichus (Orthomus) balearicus formenterrae and lately considered a member of the $O$. barbarus complex by Mateu [1957], in which it was ranked as subspecies: $O$. barbarus formenterrae, a criterion that has been followed by authors. Due to the confusion between $O$. barbarus and $O$. trapezicollis the species appeared in the catalogue of Zaballos and Jeanne [1994] as $O$. trapezicollis formenterrae. In recent works, as that of Wrase et al. [2014] and Bousquet [2017], it is again considered a subspecies of $O$. barbarus. The criterion put forward by
Zaballos and Jeanne was possibly based on the truncate apical shaft of the median lobe of aedeagus, that is not found in the populations of $O$. barbarus.

This taxon is herewith considered as a separate species due to the truncate penis and the isolation of Ibiza and Formentera. The truncate penis shape relates it to some populations of the $O$. velocissimus complex, whereas a close relationship to the $O$. barbarus complex is not supported by this character. The relatively shorter metepisterna of $O$. formenterrae, in comparison to that of $O$. velocissimus and $O$. barbarus, is other character that supports ranking this taxon as a separate species.

Dorsum dark brown, males shiny, females dull due to strong microreticulation. Body length $10 \mathrm{~mm}$. Appendices reddish brown. Eye convex, tempora short.

Pronotum notably narrowed forward, almost straight backward, anterior angle not much protruding ahead, posterior angle slightly obtuse, maximum pronotum width after middle

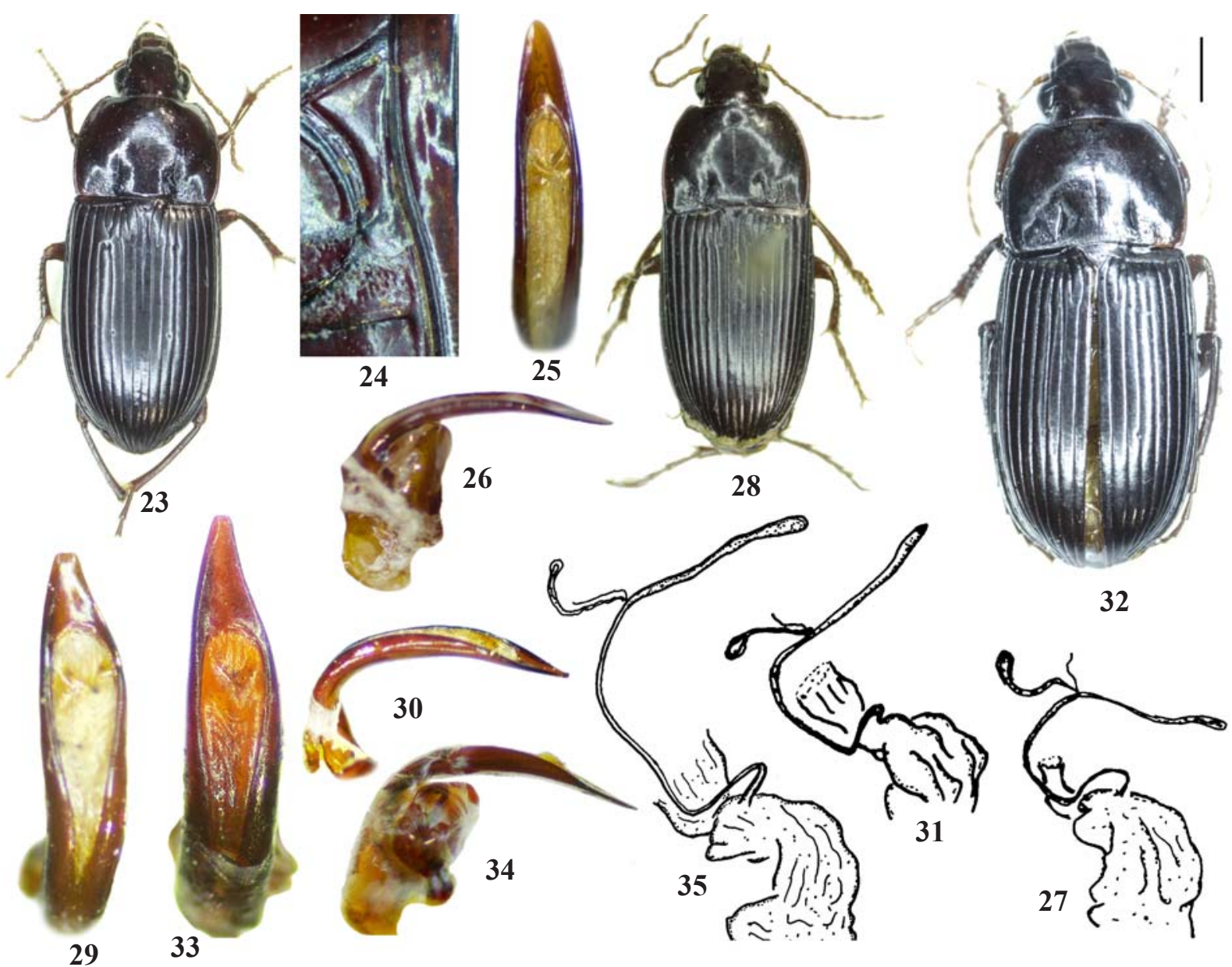

Figs 23-35. Orthomus spp, specimens from Spain: $23-27$ - O. barbarus; $28-31$ - O. formenterrae; $32-35$ - O. penibeticus; 23,28 , 32 - habitus; 24 - metepisterna; 25-26, 29-30, 33-34 - median lobe of aedeagus; 27, 31, 35 - genitalia of female; 23, 25, 28-29, 32 — dorsal view; 24, 26, 30, 34 - left lateral view; 25-26 - Cartagena, Murcia; 27 - Madrid; 29-30 - Sa-Negreta, Ibiza; 31 - Formentera Island; 32 - Almería (possibly near Adra); 33-34 -Lanjarón, Granada; 35 - Puerto del Suspiro del Moro, Sierra Nevada, Granada; 27, 31, 35 - after Ortuño [1996]. Scale bars: $1.0 \mathrm{~mm}$ (Figs 23, 28, 32).

Рис. 23-35. Orthomus spp, особи из Испании: Orthomus spp: 23-27 - O. barbarus; 28-31 - O. formenterrae; 32-35 - O. penibeticus; 23, 28, 32 - внешний вид; 24 - эпистерн заднегруди; 25-26, 29-30, 33-34 - средняя доля эдеагуса; 27, 31, $35-$ гениталии самки; 23, 25, 28-29, 32 - сверху; 24, 26, 30, 34 -сбоку слева; 25-26 - Картахена, Мурсия; 27 - Мадрид; 29-30 - СаНегрета, Ибица; 31 - о-в Форментера; 32 - Альмерия (возможно, недалеко от Адры); 33-34 - Ланхарон, Гранада; 35 - Пуэртодель-Суспиро-дель-Моро, Сьерра-Невада, Гранада; 27, 31, 35 - по Ortuño [1996]. Масштаб: 1,0 мм (Рис. 23, 28, 32). 
(Fig. 28); outer fovea moderately impressed, inner fovea deep and linear or curved; fine punctures in both foveae, postangular field moderately convex; posterior angle without tooth; basal posterior border of pronotum not emarginate.

Elytra almost parallel, regularly narrowed apicad (L/W 3.2), basis large and with a clear fold in the humeral region that forms a moderate tooth, disk pores on stria 3, parascutellar stria normally developed, striae smooth, intervals somewhat convex in males and flat in females.

Prosternal process rounded on bottom surface and forming a vertical obtuse ridge; ventrites almost smooth, punctures scarce, only somewhat rugose on sides; metepisterna smooth, relatively short (L/W 1.05) and narrowed backward. Male mesotibia dilated in apical half, metatibia with traces of crenulation.

Median lobe of aedeagus moderately curved ventrally (Fig. 30); apical shaft forming a well-developed triangle more narrowed to tip in left side (Fig. 29), truncate at tip and slightly sinuate at middle; membranous opening long, only closed near basal bulb. Characters of female genitalia as in $O$, barbarus, as duct is rather long (Fig. 31).

\section{Orthomus penibeticus Mateu et Colas, 1954, stat.n.} Figs 32-35.

This species has also been currently considered a subspecies of $O$. barbarus. However, the truncate shape of penis tip and the geographic isolation of its populations suggest that these have evolved to become a separate taxon from the surrounding $O$. velocissimus and $O$. barbarus populations, a hypothesis to be corroborated with further studies based on other characters.

Dorsum black or dark brown, appendices brown, males somewhat mat, females mat, microreticulation visible in both sexes, body length 10.0-11.7 mm. Eye convex, tempora short.

Pronotum regularly curved from anterior to posterior basis but more narrowed anteriorly, maximum width at posterior 2/ 3 (Fig. 32), posterior angle obtuse and without tooth, posterior basis not emarginate; external fovea shallow, separate from side by a flat space, internal deep and linear; punctures on posterior basis fine and with low to moderate density.

Elytra somewhat short, L/W 2.9, slightly widened backwards, humerus with small tooth; striae unpunctured, intervals moderately convex, disk pores on stria 3 , parascutellar stria well developed.

Prosternal process rounded on bottom surface and forming an acute ridge from proepisterna to bottom surface; ventral face almost devoid of punctures, metepisterna smooth and longer than wider (L/W 1.25-1.4). Male mesotibia dilated apically, metatibia with moderate crenulation although Mateu [1957] noted that the crenulation is strong, possibly because this character varies geographically.

Median lobe of aedeagus quite particular, resembling that of $O$. abacoides from Maghreb, as the apical shaft forms a long triangle asymmetrically narrowed to the left and slightly truncate at tip (Fig. 33). In lateral view the median lobe is somewhat shifted upward (Fig. 34). The female genitalia are of the $O$. barbarus type (Fig. 35), with a very long duct, longer than the spermatheca.

In addition to the geographic separation, $O$. penibeticus and $O$. abacoides differ in a number of characters, especially in the female genitalia, what suggests that similarity in male genitalia is a homoplasy.

The ranking of $O$. penibeticus as a separate species from $O$. barbarus is based on male genitalia and the geographic isolation of O. penibeticus. Although Mateu [1957] considered that the distribution of $O$. barbarus was deeply extended across Andalusia just by occupying the middle of the province of Granada (form transiens) and the eastern part of the province of Malaga (form malacensis, see map of Mateu, 1957: 113), this hypothesis is not supported on geographic grounds; instead, it is simpler to consider populations of the so-called transiens and malacensis as part of the subspecies O. velocissimus akbensis, that is found in almost the whole basin of the River Guadalquivir. This last hypothesis was put forward by Zaballos and Jeanne [1994] and followed by Serrano in successive catalogues [2003, 2013, 2020].

Accordingly, O. penibeticus would be a taxon distributed from the southern high slopes of Sierra Nevada (region of Las Alpujarras) to the Mediterranean coast, a relatively small region limited to west by the river Guadalfeo (Motril) and populations of $O$. velocissimus, and to the east by the plain between Adra and the hills west of Almería city [Mateu, 1957: 101]; in this last city it is found the southernmost populations of $O$. barbarus. This hypothesis deserves further corroboration, although at present, the study of male genitalia suffices to separate without doubt the parapatric populations of $O$. barbarus, $O$. velocissimus and $O$. penibeticus.

\section{Orthomus velocissimus (Waltl, 1835)}

Figs 36-42.

The species is notably diversified in flat and mountain areas of Andalusia where three subspecies are currently considered. The description that follows corresponds to the most widespread, O. velocissimus akbensis Mateu, 1955 (= O. andalusiacus Mateu, 1957).

Dorsum brown dark with red hue, legs dark, the other appendages brown reddish; males and females shiny, microreticulation hardly visible. Large body size, $10.8-12.7 \mathrm{~mm}$. Eye moderately protruding, tempora oblique and relatively long.

Pronotum with trapezoid shape, notably narrowed forward, almost straight backward, maximum width at middle (Fig. 36); posterior angle square, with traces of tooth in some individuals; posterior basis not emarginate; inner fovea deep and linear or curved, outer fovea diffuse; punctures of medium size and in moderate density; postangular field flat.

Elytra long and parallel, humerus with small tooth, striae smooth or with traces of punctures, intervals almost flat; 2nd dorsal pore on stria 3 or on the interval between striae 2 and 3 ; parascutellar stria normally developed, with proximal hairy pore.

Prosternal process rounded, punctures on ventral segments scarce and localized at sides, metepisterna smooth, long (L/W 1.5-1.6) and narrowed backward; male mesotibia somewhat dilated apically, metatibia only with traces of crenulation (Fig. 37).

Subspecies of $O$. velocissimus are mostly distinguished by the apical shaft of median lobe of aedeagus: it is symmetrically narrowed to tip and somewhat truncate in O. velocissimus akbensis (Fig. 39), is asymmetrical in O. velocissimus velocissimus (Fig. 40) and is truncate with apical tooth in $O$. velocissimus pardoi (Fig. 41). Likewise, O. v. akbensis has less punctures on posterior basis of pronotum and its outer fovea is less marked. The median lobe of O. v. akbensis is straight in lateral view although tip is shifted upward (Fig. 39). The female genitalia are of the $O$. barbarus type (Fig. 42).

The distribution of taxa is complex and needs the study of many more populations to ascertain precise limits. It seems that $O$. v. velocissimus is found from Tarifa (Cádiz) to the left side of River Guadalquivir near its opening to the Atlantic (Sanlúcar de Barrameda), including the plain area near Jerez, Barbate, Laguna de la Janda, Vejer de la Frontera, etc.

The area of $O$. velocissimus akbensis occupies the Guadalquivir basin, from the province of Jaén to the flooded «Marismas» 
west of Seville; in the right side of the basin it extends towards the province of Huelva and the Algarve (Faro: Portimao).

The area of $O$. velocissimus pardoi is small, a triangle between Algeciras and Fuengirola in the Mediterranean coast and Ronda to the north (i.e., the westernmost Betic mountains).
Iberian taxa: Group of Orthomus planidorsis

The group is made up by $O$. balearicus and $O$. planidorsis. It is characterized by the peculiar female genitalia in which the spermathecal duct is relatively long but the spermatheca is short and notably widened distally [Ortuño, 1996]. The medi-

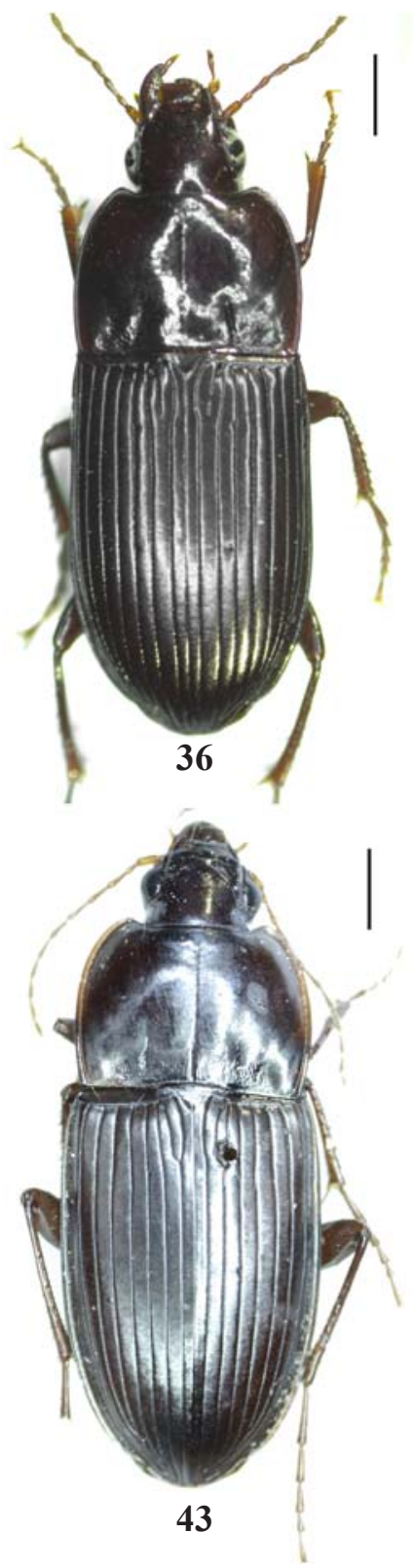

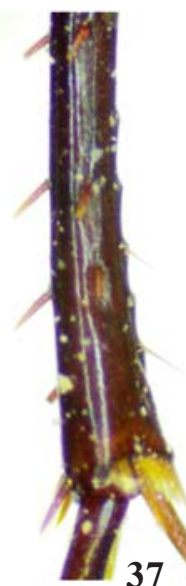

37

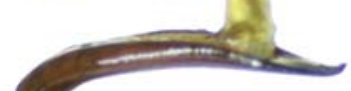

38
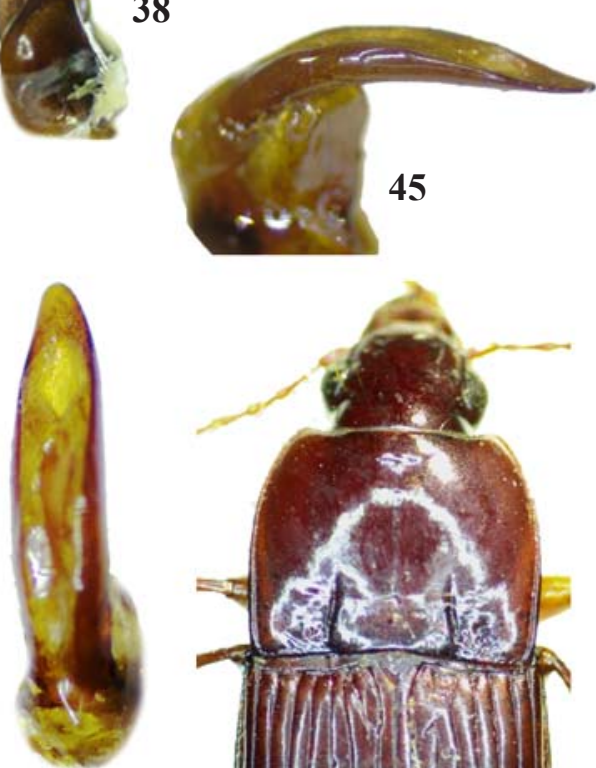

44

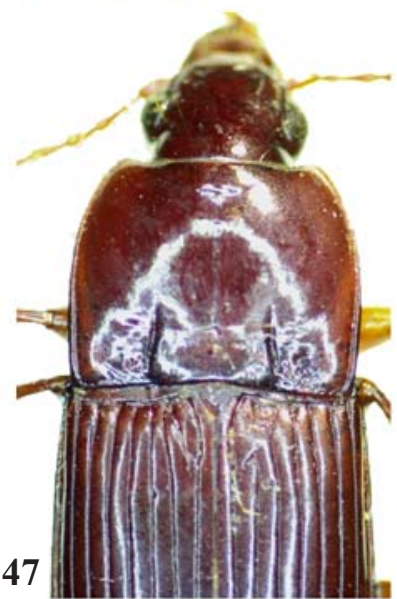

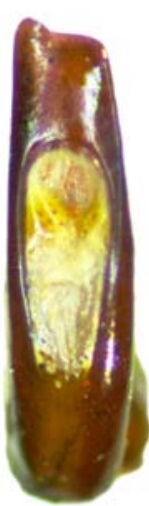

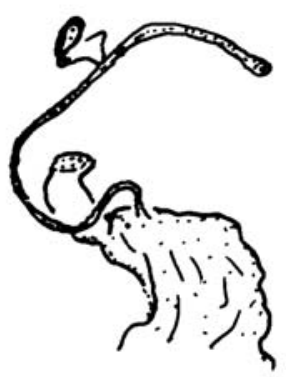

42
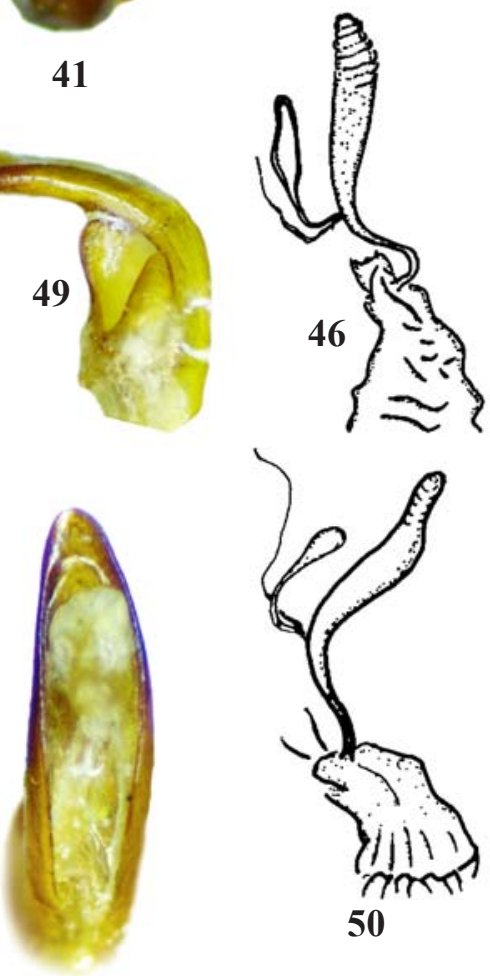

50

Figs 36-50. Orthomus spp: 36-42-O. velocissimus $(36,41-42-$ O. v. pardoi; 37-39-O. v. akbensis; $40-$ O. v. velocissimus); 43-46 - O. balearicus (43 - female); 47-50 - O. planidorsis; 36, 43,47 (in part) - habitus; 37 - hind tibia (showing weak crenulation in inner side); 38-41, 44-45, 48-49 - median lobe of aedeagus; 42, 46, 50 - genitalia of female; 36, 39-41, 43-44, 47-48 - dorsal view; 38, 45 - left lateral view; 49 - right lateral view;36, 38-39, 41 - Loja, Granada, Spain; 37 - Antequera, Málaga, Spain; 40 — Puerto Real, Cádiz, Spain; 42 - Portimão, Faro, Portugal; 43 - Inca, Mallorca, Spain; 44-45 — Palma de Mallorca, Spain; 46 — Cabo Formentor, Mallorca, Spain; 48-49 - Vernet-Les Bains, Pyrenees, France; 50 - Mont Alario, Aude, France; 42, 46, 50 - after Ortuño [1996]. Scale bars: $0.9 \mathrm{~mm}$ (Fig. 43); $1.0 \mathrm{~mm}$ (Figs 36, 47).

Рис. 36-50. Orthomus spp: 36-42-O. velocissimus (36, 41-42 - O. v. pardoi; 37-39-O. v. akbensis; $40-$ O. v. velocissimus); 4346 - O. Balearicus (43 - самка); 47-50 - O. planidorsis; 36, 43, 47 (частично) - внешний вид; 37 - задняя голень (видна слабая зубчатость по внутренней стороне); 38-47 — эдеагус; 44-45, 48-49 — средняя доля эдеагуса; 42, 46, 50 — гениталии самки; 36, 3941, 43-44, 47-48 - сверху; 38, 45 -сбоку слева; 49 -сбоку справа; 36, 38-39, 41 - Лоха, Гранада, Испания; 37 - Антекера, Малага, Испания; 40 - Пуэрто-Реаль, Кадис, Испания; 42 - Портиман, Фаро, Португалия; 43 - Инка, Мальорка, Испания; 44-45 - Пальмаде-Мальорка, Испания; 46 - Кабо Форментор, Мальорка, Испания; 48-49 - Верне-ле-Бен, Пиренеи, Франция; 50 - Мон-Аларио, Од, Франция; 42, 46, 50 — по Ortuño [1996]. Масштаб: 09 мм (Рис. 43); 10 мм (Рис. 36, 47). 
an lobe of the aedeagus is characterized by a triangular apical shaft elongate or moderately developed, and almost evenly narrowed to tip. Geographic congruence between the two species is supported by the many faunistic connections between Catalonia and the northern Balearic Islands [Serrano et al., 2015]. Other shared characters as the presence of secondary sexual characters in legs of males are not particular of the group, as are also found in the $O$. barbarus and other groups.

\section{Orthomus balearicus (Piochard de la Brûlerie, 1868)} Figs 43-46.

Dorsum black or dark brown, males not very shiny, females entirely dull, microreticulation well developed in both sexes. Large body length, 11.0-12.3 mm. Appendages reddish brown, femora dark. Eye large and convex, tempora oblique.

Pronotum almost square in some individuals (maximum width at middle, Fig. 3), or side more curved both anteriad and apicad (maximum width on apical 2/3); the most striking features are the deep and wide lateral margin, the emarginate posterior basis and the depression of the posterior basis; both foveae deep, the inner one deeper and linear, the external one large and separate from side by a flat area; punctures of posterior basis fine and from moderate to dense, mostly found within foveae; posterior angle from obtuse to almost square, devoid of tooth or with faint traces of it.

Elytra long (L/W 3.2), slightly dilated from basis, humeral tooth absent, discal pore 2 found on the 3rd stria or on interval between striae 2 and 3; parascutellar stria normally developed with proximal setigerous pore; intervals convex, striae smooth; the lateral margin of elytra is deep and wide, excavated, as is the lateral margin of pronotum.

Ventral segments with fine and scarce punctures; metepisterna longer than wide, L/W 1.35. Male mesotibia regularly dilated to apex, metatibia slightly curved, dilated in apical $1 / 6$ and with traces of crenulation.

Median lobe of aedeagus with a short triangular apical shaft (Fig. 44), more narrowed on the right side; on lateral view the penis is almost straight (Fig. 45). Female genitalia as indicated above, with a short duct and a widened spermatheca (Fig. 46).

Orthomus planidorsis (Fairmaire, 1872) Figs 47-50.

Dorsum brown, with blackish to reddish hue, shiny in both sexes as microreticulation is not much developed in females; appendages piceous red. Eye of large size, convex, tempora oblique. Body length $9.0-11.2 \mathrm{~mm}$.

Pronotum transverse with maximum width at middle (Fig. 47); from here clearly narrowed forward and almost straight backward; posterior angle slightly obtuse and not toothed; anterior angle not protruding, posterior basis not emarginate; however, lateral margin and side are clearly widened in posterior third; external fovea rugose and punctured, vaguely limited, internal one deep and linear; punctures of posterior moderately dense.

Elytra long, parallel, basis forming at humerus a small fold tooth-like. Intervals almost flat, striae deep, smooth or with traces of punctures; second disk pore adjoining stria 2 .

Prosternal process rounded with acute ridge directed toward mesosternum; ventral segments with few punctures; metepisterna longer than wide, L/W 1.3. Male mesotibia regularly dilated to apex, metatibia slightly curved, dilated in apical $1 / 6$ and without crenulation.

Median lobe of aedeagus with short triangular apical shaft, deviated to right (Fig. 48); penis in lateral view somewhat ventrally curved and elevated at tip (Fig. 49). Female genitalia (Fig. 50) as described above.

\section{Moroccan taxa: the Orthomus abacoides group}

Members of this group are $O$. abacoides and $O$. lacouri. As shown by Pupier et Coulon [2013] it is observed in the female genitalia a short spermathecal duct and a longer spermatheca distally dilated (Figs. 55, 58). On the contrary, the male genitalia are rather variable, showing from short to elongate apical shaft, this from regularly narrowed to tip to truncate at various degrees [Pupier et Coulon, 2013; Chavanon et al., 2016]. Eye convex, tempora oblique or almost perpendicular to head. Metepisterna longer than wider and narrowed posteriorly. Other morphological characters as the presence/absence of secondary sexual characters in males are found in other species groups. Geographic distribution of species and subspecies is contiguous in NE Morocco and W Algeria, with varying degrees of mixing in the case of $O$. lacouri [Chavanon et al., 2016].

\section{Orthomus abacoides (Lucas, 1846) Figs 51-55.}

Body size large, $10.4-12.4 \mathrm{~mm}$, dorsum from to black dark brown, antennae and tarsomeres red brown, femora and tibiae darker. Male shiny, female less shiny with very fine microreticulation. Eye moderately convex, tempora oblique.

Anterior angle of pronotum advanced ahead, well-marked; pronotum more narrowed forward, maximum width at middle (Fig. 51), from here slightly arcuate backward; posterior basis with few and fine punctures, inner fovea linear, outer fovea shallow, basis not emarginate; posterior angle almost straight and without tooth.

Elytra almost parallel with small tooth at humerus and clearly sinuate preapically when the epipleura meets dorsum; striae deep, smooth or with insinuated punctures; discal pores on stria 3 , intervals almost flat; parascutellar stria normally developed, with proximal hairy pore.

Ventral segments with punctures, isolated or rugose (Fig. 52). Prosternal process somewhat truncate projected backward in acute ridge. Metepisterna longer than wider (L/W 1.3). Male mesotibia regularly dilated to apex, metatibia not crenulate.

Apical shaft of median lobe of aedeagus long, asymmetrically sinuate and deviated to the left (Fig. 54), truncate at tip; in lateral view moderately arcuate ventrally (Fig. 53). Female genitalia as described above (Fig. 55).

The species is found in NW of Algeria in the region of Oran and Mostaganem, some individuals have been found in ports of south France (Marseille), surely imported. It might be found in Morocco, in the littoral near the frontier with Algeria.

\section{Orthomus lacouri (Antoine, 1941)} Figs 56-64.

According to Pupier and Coulon [2013] this species includes different geographic races that are distinguished by morphological features, and thus deserve their ranking as subspecies. Three of them are found in NE Morocco, Orthomus lacouri lacouri (Antoine, 1941); O. lacouri haroldi Pupier et Coulon, 2013, and O. lacouri kocheri Mateu, 1955. The fourth subspecies, O. lacouri pupieri Jeanne, 1988, is proper of NW Algeria. Here I follow the taxa descriptions published by Pupier and Coulon [2013] and Chavanon et al. [2016], together with personal observations of material of this species deposited in the MNCN Madrid and DZAFUM.

Male genitalia are the key characters that distinguish the subspecies, which share in common most external characters. Thus, a general description follows and peculiarities of the subspecies are indicated below. 
Dorsum from black to piceous brown, appendages brown. Body length 10.5-11.3 mm. Eye of moderate size and convex, tempora oblique. Males shiny, females shiny or somewhat dull with visible microreticulation $(O$. l. lacouri); both sexes of $O$. l. kocheri show a dull dorsum.

Pronotum shape trapezoid, anterior angle briefly protruding ahead except for $O$. lacouri haroldi, anterior basis moderately concave; side arcuate, more narrowed forward, slightly narrowed backward and showing maximum width near posterior basis (Fig. 56); posterior angle slightly obtuse and without tooth; basis no or slightly $(O$. l. haroldi) emarginate; inner fovea linear and marked, outer fovea poorly impressed; basis with points varying between scarce and moderately dense.

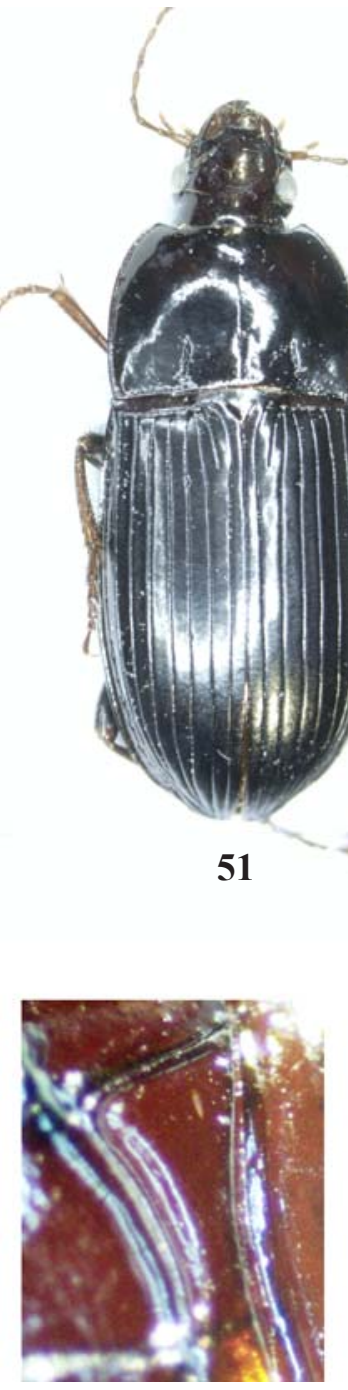

57

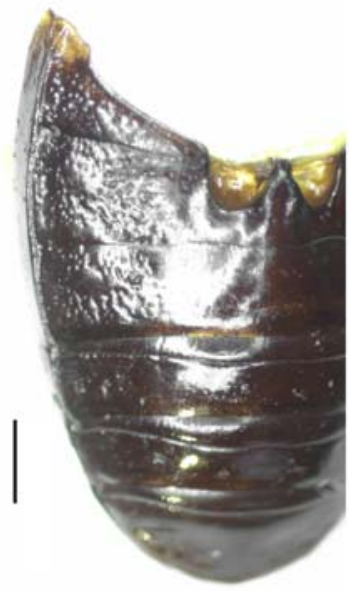

52

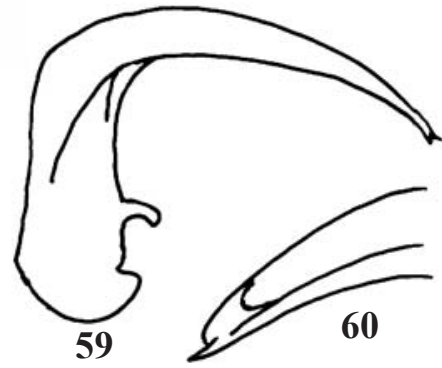

53

54

Elytra parallel, humeral tooth vestigial, striae punctured with variable intensity; discal pores on stria 3 ; 8 th interval almost vertically tumbling down to elytron margin.

Prosternal process truncate; metepisterna long, smooth and narrowed backward (Fig. 57); ventrites almost smooth, with fine punctures except for $O$. lacouri kocheri, that shows well-marked punctures; male mesotibia distally dilated, metatibia with marked crenulation in inner side of distal half.

Female genitalia (Fig. 58) with a short spermatic conduct followed by a progressively widened spermatheca of moderate length [Pupier, Coulon, 2013].

According to the detailed study of Chavanon et al. [2016], each subspecies has a "typical" shape of the median
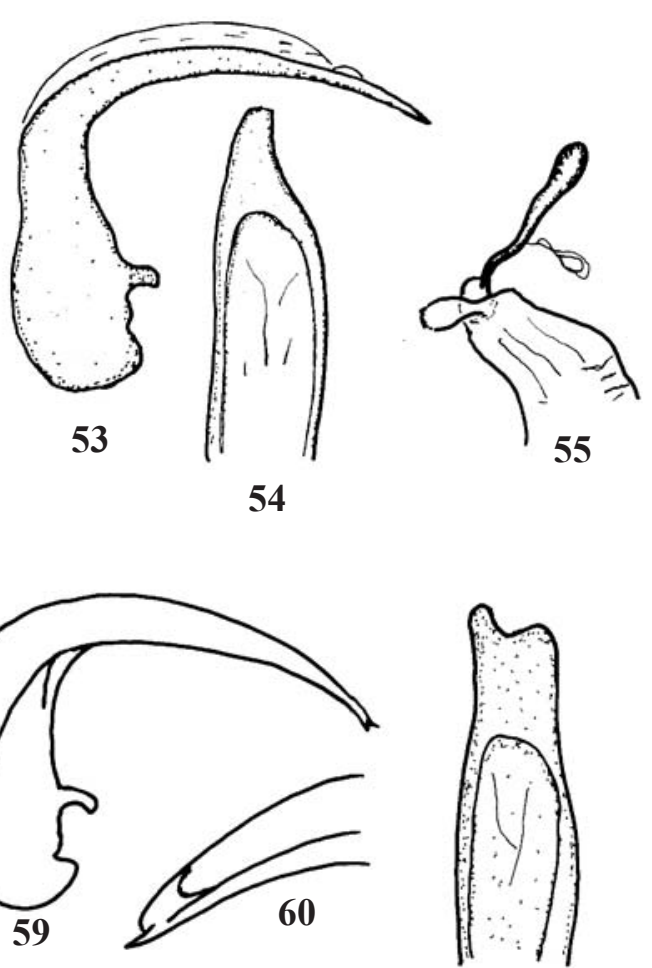

61

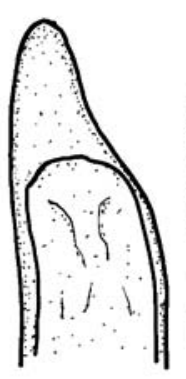

62

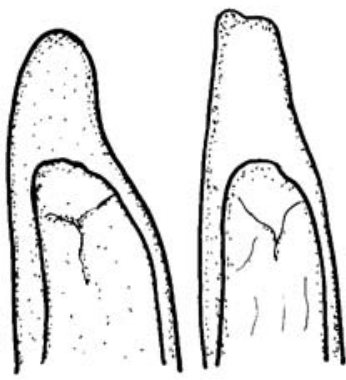

63

64

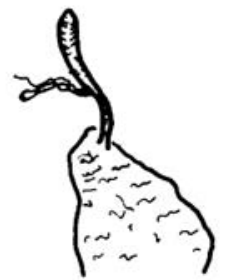

58

Figs 51-64. Orthomus spp: 51-55 - O. abacoides; 56-64 - O. lacouri (56-57, 63 - O. l. kocheri (56- female); 58-60, 62, 64 O. l. haroldi; 61 - O. l. pupieri); 51, 56 - habitus; 57 - metepisterna; 52 - punctures of abdominal segments; $53,59-$ median lobe of aedeagus; 54, 61-64 — apex of median lobe of aedeagus; 55, 58 — genitalia of female; 51, 54, 56, 61-64 - dorsal view; 57-58, 60 right lateral view; 53, 59 - left lateral view; 52 - ventral view; 51 — reservoir El Fakia, Algerie; 55, 61 — Sidi Daho ez Zahir, Algerie; 58 - Jebel Tikermine, Morocco; 62 - Tannezatte, Morocco; 63 - Farkhana, Nador, Morocco; 64 - Sidi Bouhouria, Berkane, Morocco; 53-55, 58-61 - after Pupier, Coulon [2013]; 62-64 - after Chavanon et al. [2016]. Scale bars: 1.5 mm (Fig. 51); 1.6 mm (Fig. 56).

Figs 51-64. Orthomus spp: 51-55 - O. abacoides; 56-64 - O. lacouri (56-57, 63 - O. l. kocheri (56- самка); 58-60, 62, 64 - O. l. haroldi; 61 - O. l. pupieri); 51, 56 - внешний вид; 57 - эпистерн заднегруди; 52 - пунктировка сегментов брюшка; 53, 59 - средняя доля эдеагуса; 54, 61-64 — вершина средней доли эдеагуса; 55, 58 - гениталии самки; 51, 54, 56, 61-64 - сверху; 57-58, 60 - сбоку справа; 53, 59 - сбоку слева; 52 - снизу; 51 - водохранилище Эль-Факия, Алжир; 55, 61 — Сиди Дахо эз Захир, Алжир; 58 Джебель Тикермин, Марокко; 62 - Таннезатт, Марокко; 63 - Фархана, Надор, Марокко; 64 - Сиди Бухурия, Беркане, Марокко; 53-55, 58-61 — по Pupier, Coulon [2013]; 62-64 — по Chavanon et al. [2016]. Масштаб: 1,5 мм (Рис. 51); 1,6 мм (Рис. 56). 
lobe of aedeagus, but this shape may vary notably depending on the degree of population gene flow, that results in "hybrid" shapes intermediate between those of "typical" exemplars. That paper should be consulted to check the variability; here I shall refer to the so-called "typical" shapes.

In lateral view the distal half of the median lobe of aedeagus is almost straight in $O . l$. kocheri, sinuate in $O . l$. haroldi and $O$. l. lacouri, and is ventrally bent in $O$. l. pupieri [Pupier, Coulon, 2013] (Fig. 59). In dorsal view, the apical shaft is truncate and slightly sinuate in $O$. l. lacouri (Fig. 64) and truncate with a clear tooth in $O$. . l. pupieri (Fig. 61); the other two subspecies show a rounded apex, sinuate to the left, being wider in O. l. kocheri [Pupier, Coulon, 2013; Chavanon et al., 2016] and slender and more elongate in $O . l$. haroldi (Figs 62-63).

According to the map provided by Chavanon et al. [2016] the subspecies $O . l$. kocheri is found west of River Muluya whereas O. l. lacouri is found in the surroundings of Oujda and the Algerian border, to the west near Berkane, El Aioun and Guerfane; O. l. haroldi is found in-between the other two subspecies. Hybrids between these subspecies are found in many contact areas.

\section{Moroccan taxa: the Orthomus berytensis group}

Possible members of this group are $O$. berytensis and $O$. dimorphus. The group is only supported by the weak or null manifestation of secondary sexual characters in male mesoand metatibia. The apical shaft of the median lobe of the aedeagus is relatively similar: a short or moderately elongate shaft almost evenly narrowed to tip. The female genitalia (this paper) differ between these two species. In O. berytensis it is somewhat similar to that described for taxa of the $O$. barbarus and $O$. velocissimus groups, with a long and filiform duct and spermatheca (Fig. 70), whereas that of O. dimorphus show a much longer spermatheca (Fig. 75) that becomes rather thick in fertilized females (Fig. 76). These two species also differ in the pronotum shape and other characters, what makes the group subjected to future corroboration.

\section{Orthomus berytensis (Reiche et Saulcy, 1855)} Figs 65-70.

Dorsum black to dark brown, often with reddish hue, shiny in both sexes (females show fine microreticulation), appendices with lighter coloration brown red. Body length variable $8.0-11.0 \mathrm{~mm}$. Eye convex, protruding, tempora oblique.

Pronotum transverse almost rectangular, regularly curved, well narrowed forward and moderately backward, maximum width near middle (Fig. 65), anterior angle briefly projected forward, anterior basis almost regularly arcuate; posterior angle obtuse with a tiny tooth (Fig. 66), posterior basis beaded up to the origin of the inner fovea; external fovea weakly impressed, inner fovea linear; punctures usually in low density or entirely absent (in East Mediterranean populations punctures are more abundant); space between external fovea and side somewhat convex.

Elytra slightly enlarged from basis, humerus with a small and non-protruding tooth, striae smooth or with traces of punctures, intervals flat, discal pores on stria 3 .

Prosternal process slightly truncate; ventral segments with shallow punctures at sides (Fig. 67), metepisterna smooth. Male mesotibia slightly dilated apically, metatibia moderately crenulate.

Apical shaft of median lobe of aedeagus wide and with trapezoid shape, only briefly narrowed to tip (Fig. 68), in lateral view somewhat ventrally bent (Fig. 69). The female genitalia match in all details the characters described by Ortuño [1996] for the O. barbarus and O. velocissimus groups, in that there is a long spermathecal duct (where a caecum is originated) followed by a long a slightly dilated spermatheca toward apex (Fig. 70). Therefore, this pattern clearly differs from that found in the other Maghrebian taxa [Pupier, Coulon, 2013]. These findings suggests that the species is more closely related to the north Mediterranean lineages than to the Maghrebian ones. However, the species occupies the whole North Africa, and to the east occupies Israel, Lebanon, Syria, Turkey, Cyprus and Greece, that is, a North African geographic pattern. Indeed, it is also found in Sicily, Sardinia and Malta, and to west reaches the southernmost parts of Morocco and the Canary Islands. Analyses of new characters are needed to better assess its phylogenetic affinities.

\section{Orthomus dimorphus Antoine, 1933} Figs 71-76.

This species has two subspecies, $O$. dimorphus antoinei Mateu, 1955 and $O$. dimorphus dimorphus Antoine, 1933. The following description is based on the first one, that is more common in Atlantic Morocco than the nominal subspecies, that is restricted to some localities of Great Atlas over 2000 m.a.s.1.

Dorsum dark brown, appendices brown, male shiny, female mat, microreticulation well visible in females, weak in males. Body length variable within populations and between subspecies, 7.0-12.0 $\mathrm{mm}$. Eyes moderately convex and protruding, tempora long.

Pronotum somewhat trapezoid, maximum width after middle (Fig. 71), side curved and narrowed forward, only narrowed backward near posterior angle; this shows a small protruding tooth; posterior basis beaded up to inner linear fovea; external fovea variably impressed; punctures variable in density and size, usually fine and in moderate density; postangular field convex.

Elytra slightly widened from basis; humerus with a small and non-protruding tooth, parascutellar stria well-developed with proximal seta; striae smooth but with traces of punctures; intervals flat.

Prosternal process somewhat rounded. Metepisterna smooth, long and narrowed backward (Fig. 72). Ventral segments laterally smooth or with fine and few punctures. Male mesotibia not distally dilated; male metatibia only slightly curved and without crenulation in distal inner side.

Median lobe of aedeagus with an elongate apical shaft (Fig. 73), almost evenly narrowed apicad, and almost straight in lateral view (Fig. 74); membranous area notably prolonged toward the bulb.

Spermatheca notably longer than duct (Fig. 75), it becomes notably thick after fertilization (Fig. 76). This shape difference within the same species calls attention on the variable aspect that may take the female genitalia of $\mathrm{Or}$ thomus depending on matureness and fertilization.

The subspecies $O$. dimorphus dimorphus occupies the Great Atlas above $2000 \mathrm{~m}$. Its body length is smaller (less than $10 \mathrm{~mm}$ ), the female is mat, the pronotum basis is almost smooth, the humeral tooth is small, the striae are almost smooth, and the median lobe of aedeagus is ventrally curved upwards, with an apical shaft that forms a relatively short triangle.

The subspecies $O$. dimorphus antoinei is of larger body length and both sexes are dorsally shiny. The pronotum basis is punctured, the external fovea is better marked, the striae of 
elytron are well impressed and punctured, the humeral tooth is developed. The median lobe of aedeagus is almost straight on distal half in lateral view; in dorsal view it shows a more elongate and triangular apical shaft. This subspecies is found in the Atlantic plain of Morocco and doesn't enter in the Rif and the Great Atlas above $2000 \mathrm{~m}$. See Antoine [1957] for further details.
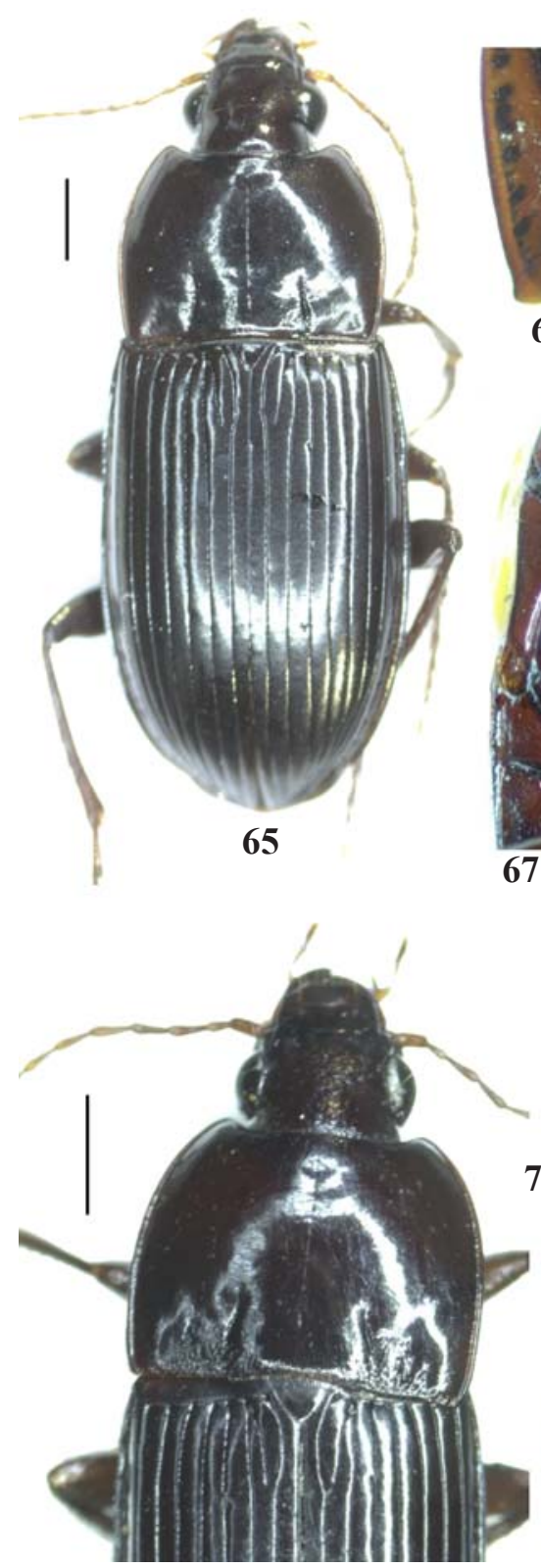

71
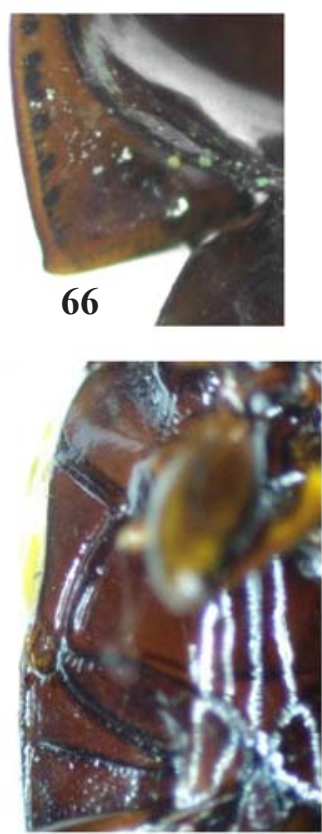

67

72
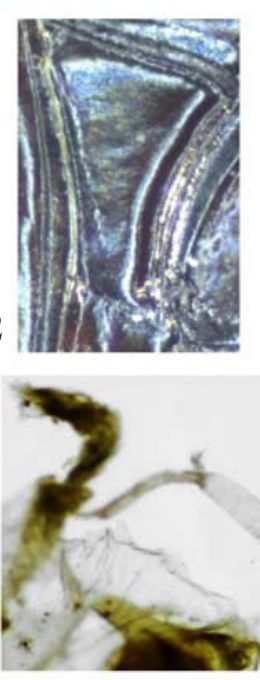

75
KEY TO SPECIES

1. Metepisterna short, longer in anterior border than its length from middle anterior border to middle posterior border (Figs 6, 13) (in O. maroccanus it is equally long as wide), and no or slightly narrowed backward...

- Metepisterna long, anterior border shorter than its length

Figs 65-76. Orthomus spp, specimens from Morocco: 65-70 - O. berytensis; 71-76-O. dimorphus antoinei; 65, 71 (in part) habitus; 66 - posterior angle of pronotum (in part); 67 - metepisterna and ventrites (in part); 72 - metepisterna; 68-69, 73-74 - median lobe of aedeagus; 70 - spermatheca and spermathecal duct (in part); 75 - empty spermatheca of young female; 76 - full spermatheca of mature female; 65, 68, 71, 73 - dorsal view; 66 - ventral view; 69, 74 - left lateral view; 72 - right lateral view; 67, 70 - Essaouira; 68-69 - Agadir; 73, 76 - Rabat (plage); 75 - Meknés. Scale bars: 1.5 mm (Fig. 71); 2.0 mm (Fig. 65).

Рис. 65-76. Orthomus spp, особи из Марокко: 65-70-O. berytensis; 71-76-O. dimorphus antoinei; 65, 71 (частично) 一 внешний вид; 66 - задний угол переднеспинки (частично); 67 - эпистерн заднегруди и вентриты (частично); 72 - эпистерн заднегруди; 68-69, 73-74 - средняя доля эдеагуса; 70 - сперматека и её проток (частично); 75 - пустая сперматека неполовозрелой самки; 76 - полная сперматека половозрелой самки; 65, 68, 71, 73 - сверху; 66 - снизу; 69, 74 - сбоку слева; 72 - сбоку справа; 67 , 70 - Эс-Сувейра; 68-69 - Агадир; 73, 76 - Рабат (пляж); 75 - Мекнес. Масштаб: 15 мм (Рис. 71 ); 20 мм (Рис. 65). 
measured from middle anterior to middle posterior border, and clearly narrowed backward (Figs 20, 57) ..... 8

2. Eyes flat, tempora long, metepisterna slightly narrowed backward. Female genitalia made up by a short spermathecal duct and a short and and moderately dilated spermatheca toward apex (Figs 4, 9). Median lobe of aedeagus ventrally bent at various degrees, apical shaft triangular and almost equally narrowed at apex (Fig. 3)

\section{O. maroccanus group}

- Eyes convex, tempora moderately long, metepisterna short and narrowed backward (Fig. 13). Female genitalia with a short $(O$. aubryi) or somewhat longer (O. hispanicus, $O$. perezii) spermathecal duct, and a progressively widened spermatheca (Figs 15, 18). Median lobe of the aedeagus not markedly bent ventrally; apical shaft varying between equally narrowed apicad $(O$. perezii) or with asymmetrical shape $(O$. hispanicus, Fig. 14) .......

6. O. hispanicus group

3. Basal foveae of pronotum distinct and with dense punctures (Fig. 1). Anterior angle of pronotum well-marked. Male shiny, female dull with strong microreticulation. Male mesotibia dilated in apical half, metatibia slightly curved and weakly crenulate in inner side of apical third. Body length 8.0-9.8 mm. North and West Morocco, southernmost tip of Andalusia ................... Orthomus maroccanus Chaudoir

- Basal foveae of pronotum poorly impressed, with few and irregular punctures, or smooth. Anterior angle of pronotum moderately protruding (Fig. 5). Male shiny, female moderately shiny with shallow microreticulation. Male mesotibia not dilated in apical half, metatibia not curved and without crenulation .............................................. 4

4. Pronotum narrowed backward and sinuate before posterior angle. Metatibia of male not crenulate. Humerus with small tooth. Apical shaft of aedeagus slightly deviated to right (Fig. 11). Body length 7.8-9.2 mm. Northwest region of Taza ....... Orthomus starkei Wrase et Jeanne.

- Pronotum slightly narrowed backward, not sinuate before posterior angle (Fig. 5). Elytra with humeral tooth. Mesotibia of male crenulate. Last ventrites with fine punctures (Fig. 6). Spermatheca notably dilated apicad when full (Fig. 9). Body length 7.3-9.7 mm

5. Orthomus tazekensis (Antoine)

5. Parascutellar stria with scutellar pore. Crenulation of metatibia of male well developed (it consists of about 8 marked tubercles). Apical shaft of the median lobe not rounded, asymmetrically narrowed in left side; membranous sac moderately open toward basal bulb. Northermost area of Moyen Atlas: Jbel Tazzeka

Orthomus tazekensis tazekensis (Antoine)

- Parascutellar stria without scutellar pore. Crenulation of male metatibia weakly developed (it consists of about 6 tubercles). Apical shaft of the median lobe shorter and almost evenly rounded apically (Fig. 7); open membranous sac extending toward basal bulb. Spermatheca notably dilated apicad after fecundation (Fig. 9). Rif Massif Orthomus tazekensis rifensis Wrase et Jeanne

6. Maximum pronotum width after middle (Fig. 12), more narrowed forward, posterior angle with small tooth; humeral angle of elytron toothed; discal pore 2 on 3rd stria. Ventral segments with punctures (Fig. 13). Apical shaft of median lobe of aedeagus asymmetrical, more narrowed and sinuate in the left side; membranous area of the median lobe of aedeagus briefly open. Spermatheca longer than the duct and notably dilated apicad (Fig. 15). Body length 7.0-8.5 mm. Northern half of Portugal, Galicia, Cantabrian Mountains, Northern Sistema Ibérico, and
Sistema Central from Serra da Estrela to sierra de Gredos Orthomus. hispanicus (Dejean) Maximum pronotum width at middle, side slightly constricted backward, posterior angle with very small tooth; humeral angle of elytron not toothed; discal pore 2 on 2 nd stria or laying on interval 2-3. Apical shaft of median lobe of aedeagus almost symmetrically narrowed to tip; membranous area of the median lobe of aedeagus notably open toward basal bulb. Body length $6.0-10.0 \mathrm{~mm}$............ 7

7. Smaller body length, $6.0-7.7 \mathrm{~mm}$. Outer fovea of pronotum basis marked with marked ridge toward side (Fig. 16). Elytra relatively short and oval, $\mathrm{L} / \mathrm{W}<3$. Apical shaft of median lobe of aedeagus in short symmetrical triangle (Fig. 17). Female genitalia as in O. hispanicus (Fig. 18). Sistema Central, Sistema Ibérico ( $\mathrm{N}$ and $\mathrm{S})$, North Meseta, northern part of South Meseta...

Orthomus perezii (Martínez-Sáez)

- Larger body length, $6.0-10.5 \mathrm{~mm}$. Outer fovea of pronotum less, faint. Elytra relatively long and parallel, L/W 3.41 (Fig. 19). Apical shaft of median lobe of aedeagus forming an elongate triangle (Fig. 20), somewhat more narrowed in the left, tip curved upward (Fig. 21). Female genitalia somewhat distinct due to a longer duct (Fig. 22). Basque Mountains, Northern Sistema Ibérico, central and western Pyrenees .................... Orthomus aubryi Jeanne

8. Species inhabiting the Iberian Peninsula, South France and Balearic Islands .................................................... 9.

- Species inhabiting Morocco (taxa on the Algerian border near Oujda are included) ......................................... 16.

9. Female genitalia with a long spermathecal duct followed by a long spermatheca (Figs 27,31). Male genitalia rather variable. Dorsum of both sexes shiny. Second dorsal pore adjoining 3rd stria. Taxa distributed from southwest Iberia (Algarve and western Andalusia) northward to the River Ebro basin, across the oriental half of the Peninsula and South France ..................... 10 group O. barbarus

- Female genitalia with a long spermathecal duct followed by a short and progressively widened spermatheca (Figs $46,50)$. Apical shaft of median lobe of aedeagus usually in short triangle almost symmetrically narrowed. Dorsum of female $(O$. planidorsis) or of both sexes with strong microreticulation $(O$. balearicus). Second dorsal pore adjoining 2nd stria (O, planidorsis) or 3rd stria $(O$. balearicus). Catalonia, South France (Roussillon), Mallorca and Menorca ................. 15 group $O$. planidorsis

10. Pronotum side arcuate, more narrowed forward, maximum width after middle (Fig. 23); posterior angle of pronotum slightly obtuse, usually with a small tooth; postangular field convex. Humeral angle toothed. Metepisterna smooth (Fig. $24)$, ventrites with light punctures. Male mesotibia hardly dilated in second half, metatibia with reduced crenulation on inner side of distal half (except for Logroño populations). Apical shaft of median lobe of aedeagus forming an elongate triangle (Fig. 25) symmetrically narrowed or deviated to the right, usually ending in an acute angle, almost straight in lateral view (Fig. 26). Body length 9.0 $11.5 \mathrm{~mm}$. Mediterranean coast from Almeria to south France, South Meseta, Betic and Iberian chains, River Ebro basin ............... Orthomus barbarus barbarus (Dejean)

- Pronotum arcuate, maximum width at middle or after it (O. velocissimus), slightly narrowed backward; posterior angle of pronotum with or without a small tooth; postangular field almost flat. Humeral angle not toothed or with a minute tooth hard to see. Male mesotibia dilated variably depending on the species, metatibia with reduced crenulation on inner side of distal half (except for $O$. 
penibeticus). Apical shaft of median lobe of aedeagus rather variable, never in symmetrical triangle .......... 11

11. Species from Ibiza and Formentera, maximum width at middle (Fig. 28); elytron with a wide basal margin that ends in a fold making up a humeral tooth. Striae smooth. Male mesotibia distally dilated, metatibia with traces of crenulation. Median lobe of aedeagus ended with a truncate line (Fig. 29), more narrowed in the left, ventrally bent (Fig. 30). Female genitalia with both long duct and spermatheca (Fig. 31). Body length $10 \mathrm{~mm}$....................

\section{Orthomus formenterrae (Breit)}

- Species from southern Iberia. Margin of elytron normally developed, ending in a small humeral tooth ............. 12

12. Maximum width of pronotum at middle (Fig. 32), more arcuate forward; posterior angle of pronotum without trace of small tooth. Striae smooth, without traces of punctures. Male mesotibia dilated in apical half, metatibia with clear crenulation in inner side of distal half. Median lobe of aedeagus with truncate apex (Fig. 33) slightly ventrally bent (Fig. 34). Female genitalia with a duct even longer than the spermatheca (Fig. 35). Body length 10.0-11.5 mm. Distributed in the Alpujarras region of south Sierra Nevada, reaching the coast between Motril and Roquetas de Mar (Almería) ......... Orthomus penibeticus (Mateu et Colas)

- Maximum width of pronotum after middle (Fig. 36), clearly narrowed forward; posterior angle of pronotum with a small tooth not visible in rare individuals; external fovea shallow, punctures in moderate density. Striae smooth or with traces of punctures. Male mesotibia poorly dilated in apical half, metatibia often with vague traces of crenulation in inner side of distal half (Fig. 37). Spermathecal duct longer than the spermatheca (Fig. 42). Large size, body length $10.8-12.7 \mathrm{~mm}$. Andalusia and Algarve ................. 13. Orthomus velocissimus (Waltl)

13. Posterior basis of pronotum with few punctures and outer fovea rather shallow. Apical shaft of median lobe of aedeagus obtusely rounded (Fig. 48) and deviated to left. Distributed across the Guadalquivir basin, from the province of Jaén to the flooded «Marismas» west of Seville; in the right side of the Basin it extends across the province of Huelva and the Algarve (Faro, Portimao)

Orthomus velocissimus akbensis Mateu

- Posterior basis of pronotum with moderate to higher density of punctures; outer fovea usually well outlined. Apical shaft of median lobe of aedeagus rounded or truncate and toothed 14

14. Apical shaft of median lobe of aedeagus more narrowed in the left side, asymmetrical, and tip obtusely rounded (Fig. 40). From Tarifa (Cadiz) to the left side of River Guadalquivir near its opening to the Atlantic (Sanlúcar de Barrameda), including the flat area close to Jerez ..........

Orthomus velocissimus velocissimus (Waltl)

- Apical shaft of median lobe of aedeagus truncate and toothed (Fig. 41). Proper of the sierra de Ronda slopes, reaches the Mediterranean coast between Algeciras and Fuengirola ........ Orthomus velocissimus pardoi Mateu

15. Species with the largest body size within the genus, 11.0 $12.3 \mathrm{~mm}$. Strong microreticulation in both sexes, males scarcely shiny. Lateral margin of pronotum wide and deep (Fig. 43), side raised; posterior basis emarginate from angle to inner fovea, as well as the anterior margin; posterior basis depressed. Humeral tooth absent or rather minute. Apex of median lobe of aedeagus in short triangle (Fig. 44), almost straight in lateral view (Fig. 45). Female genitalia (Fig. 46) as described above. Balearic islands: Mallorca and Menorca .......... Orthomus balearicus (Piochard de la Brulerie)
- Body length smaller than $11 \mathrm{~mm}$. Body shape narrower, convex, at least males shiny. Lateral margin of pronotum deep but not raised; posterior basis not emarginate (Fig. 47) and not depressed, anterior basis only slightly bordered toward middle; punctures of moderate to high density. First discal pore on stria 3,2 nd on interval $2-3$ or adjoining stria 2; stria deep, intervals convex. Humeral tooth resulting from small folding of elytron basis. Apical shaft of median lobe of aedeagus ending in a brief triangle (Fig. 48), somewhat bent upward in lateral view (Fig. 49). Spermatheca wide and longer than duct (Fig. 50). From Catalonia to Roussillon ................ Orthomus planidorsis (Fairmaire)

16. Female genitalia including a moderately long spermathecal duct followed by a short spermatheca progressively widened apicad. Median lobe of aedeagus showing a variable shape of apical shaft between truncate, toothed or rounded. Male usually showing differential characters in meso- and metatibia. Eastern Morocco, West Algeria ..

17. group $O$. abacoides

- Female genitalia include a long spermathecal duct followed by an elongate spermatheca not widened apically ( $O$, berytensis), or with other pattern ( $O$. dimorphus). Apical shaft of penis short, wide and broadly rounded $(O$. berytensis), or elongate and with sharpen tip (O. dimorphus). Males without sex characters in legs, these only insinuated in $O$. berytensis. This last species shows a vast geographic distribution whereas $O$. dimorphus is found from Atlantic plain of Morocco to montane areas of Great Atlas ...................................... 21. group $O$. berytensis

17. Anterior angle of pronotum advanced ahead; maximum width of pronotum after middle (Fig. 51), narrowed and arcuate forward, less narrowed backward; posterior angle with small tooth; posterior basis not beaded; inner fovea deep and linear, outer poorly impressed, punctures abundant. Elytron with marked preapical sinuosity where the epipleuron reaches dorsum, humerus not toothed. Ventrites with fine and rugose punctures (Fig. 52). Male mesotibia not dilated distally, metatibia only with traces of crenulation. Apical shaft of median lobe of aedeagus truncate and notably deviated to left (Fig. 54). Northwest Algeria Orthomus abacoides (Lucas)

- Anterior angle of pronotum moderately projected ahead; maximum width of pronotum in posterior $3 / 4$, briefly narrowed backward (Fig. 56); posterior angle without small tooth; posterior basis beaded $(O$. lacouri haroldi) or not; inner fovea deep and linear, outer almost faint, punctures in variable density. Elytron with slight preapical sinuosity, humerus with small tooth. Ventrites almost smooth (Fig. 57). Male mesotibia dilated, metatibia with moderate crenulation. Apical shaft of median lobe of aedeagus much diverse depending on the subspecies. Northeast Morocco, northwestern Algeria .... 18. Orthomus lacouri (Antoine)

18. Ventrites with gross punctures on sides. Apical shaft of median lobe of aedeagus large (Fig. 63), both elongate and wide, tip rounded, notably arcuate in left side. From the surroundings of Nador and Melilla to the River Muluya to the East ..................... Orthomus lacouri kocheri Mateu

- Ventrites smooth or with few punctures. Apical shaft of median lobe of aedeagus truncate with tooth, or only slightly truncate, or rounded but slender than that of $O$. v. kocheri. Regions east of River Muluya .................... 19

19. Posterior basis of pronotum slightly beaded, anterior angle advanced ahead. Ventrites smooth. Male mesotibia clearly dilated distally. Apical shaft of median lobe of aedeagus similar to that of $O$. v. kocheri but narrower and slender (Fig. 62), strongly sinuate in the left side before 
the apical shaft. Spermatheca wide and widened apically, relatively short, longer than duct (Fig. 58). It occupies a small area between the Muluya and the region delimited by Berkane, Taforalt, El Aïoun .....

Orthomus lacouri haroldi Pupier et Coulon

- Posterior basis of pronotum not beaded. Ventrites smooth or with fine lateral punctures. Male mesotibia dilated, metatibia crenulate. Apical shaft of median lobe of aedeagus truncate, only slightly sinuate (O. lacouri lacouri) or having a prominent tooth $($ O. lacouri pupieri) ......... 20

20. Populations inhabiting northernmost part of Morocco (surroundings of Oujda), distribution in western Algeria unknown. Apical shaft of median lobe of aedeagus obliquely truncate, border slightly sinuate (Fig. 64) Orthomus lacouri lacouri (Antoine).

- Populations inhabiting Sidi Daho des Zaïr (Willaya Sidibel-Abbés, NW Algeria). Apical shaft of median lobe of aedeagus truncate and provided with a tooth (Fig. 61) ... O. lacouri pupieri Jeanne

21. Male and female shiny (microreticulation very fine in the female). Maximum pronotum width at middle (Fig. 65), anterior angle of pronotum advanced; posterior angle with a small tooth (Fig. 66); outer fovea poorly impressed, punctures variable; posterior basis beaded up to the origin of inner fovea. Metepisterna smooth (Fig. 67), ventrites with scarce punctures. Male mesotibia slightly dilated in distal half, metatibia only with traces of crenulation. Apical shaft of median lobe of aedeagus large, not much elongate but wide and almost symmetrically narrowed to tip (Fig. 68), ventrally bent (Fig. 69). Female genitalia of the $O$. barbarus type: long spermathecal duct followed by a long and slender spermatheca (Fig. 70). Ubiquitous species; it is unknown whether populations of entire North Africa are connected or are isolated in particular areas. Size larger $(8.0-11.0 \mathrm{~mm})$ than that of $O$. dimorphus ............. Orthomus berytensis (Reiche et Saulcy)

- Size usually smaller $(7.0-12.0 \mathrm{~mm})$ than that of O. berytensis. Male shiny, female dull (microreticulation more developed). Maximum width of pronotum after middle (Fig. 71), side notably narrowed forward; anterior angle of pronotum moderately projected ahead; posterior angle with small tooth; outer fovea well impressed (O. dimorphus antoinei) or shallow (O. dimorphus dimorphus), punctures variable; posterior basis at most finely beaded. Metepisterna smooth (Fig. 72), ventrites with scarce punctures. Male legs without sex characters. Apical shaft of median lobe of aedeagus more elongate and symmetrically narrowed to tip (Fig. 73), in lateral view the penis is slightly ventrally bent but apex is shifted upward (Fig. 74). Female genitalia rather peculiar due to the presence of a short spermathecal duct and a moderately large and cylindrical spermatheca (Figs 75-76), widened apicad. Morocco ................ 22. Orthomus dimorphus Antoine

22. Size smaller (less than $10 \mathrm{~mm}$ ). Female dorsum mat, microreticulation strong; posterior basis with shallow external fovea, smooth or with scarce punctures. Humeral tooth small, striae smooth. Apical shaft of median lobe of aedeagus shorter and asymmetrically narrowed to tip. Central Grand Atlas, over 2000 m Larger size, usually length over $10 \mathrm{~mm}$. Female dorsum relatively shiny; posterior basis with well-marked foveae and punctured. Humeral tooth somewhat larger. Apical shaft of median lobe of aedeagus more elongate and symmetrically narrowed. Atlantic plain of Morocco, northwards up to Larache and Rif region; to the East reaches
Grand Atlas below 2000 m; Moyen Atlas; to the NE up to Guercif ............. Orthomus dimorphus antoinei Mateu

Acknowledgements. This paper is dedicated to the memory of Prof. Inessa Kh. Sharova who has given us notable contributions to understand the tight relationships between morphology and life forms of ground beetles.

I acknowledge the great help and facilities received from Mercedes Paris, Curator of Entomology in the National Museum of Natural Sciences of Madrid, when visiting and consulting the material of Orthomus from both Iberia and North Africa deposited there. Own material of Orthomus was collected during many decades, thanks to the support of the University of Murcia, the Seneca Agency supporting research in Murcia and the Spanish agencies supporting research, as the ANEP.

Many friends and colleagues have contributed with plenty of captures to the Orthomus stock of the collection deposited in the Department of Zoology and Physical Anthropology of Murcia. My gratitude to all of them.

\section{References}

Aguiar C.A.S., Serrano A.R.M. 2013. Catálogo e atlas dos Coleópteros Carabídeos (Coleoptera, Carabidae) de Portugal Continental // Lisboa: Sociedade Portuguesa de Entomología. 265 pp.

Antoine M. 1957. Coléoptères Carabiques du Maroc (deuxième partie) //Mémoires de la Société des Sciences Naturelles et Physiques du Maroc, Zoologie (nouvelle série). Vol.3. P.179-314.

Bonadona P. 1979. A propos d'Orthomus barbarus (Col. Carabidae) // L'Entomologiste. Vol.35. No.6. P.238-244.

Bousquet Y. 2017. Tribe Pterostichini // Löbl L., Löbl I. (eds.). Catalogue of Palaearctic Coleoptera. Vol.1. Archostemata Myxophaga - Adephaga. Leiden: Brill. P.469-521.

Chavanon G. 2018. Catalogue des Coléoptères de la region orientale du Maroc (Province de Guercif exceptée) // Trav. l'Instit. Sci. Série Zoologie. No.57. Rabat. 193 pp.

Chavanon G., Mabrouki Y., Taybi F.A. 2016. Sur la répartition des populations d'Orthomus lacouri (Antoine, 1941) (Coleoptera, Carabidae, Pterostichinae) dans les Beni Snassen (Maroc Oriental) // Bull. mens. Soc. linn. Lyon. Vol.85. Nos5-6. P.173-186.

Coulon J., Pupier R., Queinnec E., Ollivier E., Richoux P. 2011. Coléoptères Carabidae de France: Compléments aux 2 volumes de René Jeannel. Mise à jour, corrections et répertoire // Faune de France. Vols 94-95. 352 pp.

Fuente J.M. de la 1927. Tablas analíticas para la clasificación de los coleópteros de la Península Ibérica. Adephaga: 1 Cicindelidae, 11 Carabidae. 1. Barcelona: Bosch. 415 pp.

Giachino P.M., Sciaky R. 1991. Valore sistematico delle structure genitali femminili in Pterostichinae (Coleoptera: Carabidae) // Atti XVI Congresso nazionale italiano d'Entomologia, Bari. P.885-892.

Guéorguiev B., Wrase D.W. 2016. On the identity of Orthomus hespericus Motschulsky, 1849 (Coleoptera: Carabidae: Pterostichini) // Ecol. Mont. Vol.5. P.28-34.

Guéorguiev B., Wrase D.W., Farkaè J. 2014. Revision of the East Mediterranean Orthomus (Coleoptera, Carabidae, Pterostichini), with description of Parorthomus gen. n. socotranus sp. n. from Socotra Island and key to the Old World genera of subtribe Euchroina // ZooKeys Vol.427. P.21-57.

Jeanne, C. 1966. Carabiques de la Péninsule Ibérique (2e note) // Act. Soc. linn. Bordeaux. Vol.102. No.10. [1965]. P.3-34.

Jeanne C. 1974. Carabiques nouveaux (5eme note) // Bull. Soc. ent. France. Vol.79. P.66-71.

Jeanne C. 1981. Carabiques de la Péninsule Ibérique (3eme supplément) // Bull. Soc. linn. Bordeaux. Vol.8. [1978-1980]. P.21-47.

Jeanne C. 1988. Carabiques noveaux ou remarquables (9eme note) // Bull. Soc. linn. Bordeaux. Vol.16. P.69-87.

Jeannel R. 1942. Coléoptères Carabiques. Faune de France. Vol.40. 
P.572-1173. París: Lechevalier.

Machado A. 1992. Monografía de los carábidos de las Islas Canarias. La Laguna: Instituto de Estudios Canarios. 734 pp.

Mateu J. 1951. El género Orthomus Chaud. en las islas atlántidas (Col. Carabidae) // Eos. Vol.27. P.277-289.

Mateu J. 1954a. Notas sobre los Orthomus Chaudoir I. //Eos. Vol.30. P.353-361.

Mateu J. 1954b Contribución al conocimiento de los Sphodrini Cast. y Poecilini Bon. de las Islas Canarias (Col. Carabidae) // Arch. Instit. Aclimat. Almeria. Vol.3. P.7-27.

Mateu J. 1955. Notas sobre los Orthomus Chaudoir (segunda nota) // Eos. Vol.31. P.53-85.

Mateu J. 1957. Notas sobre los Orthomus Chaudoir (tercera nota) // Eos. Vol.33. P.87-112.

Ortuño V.M. 1996. La genitalia femenina en los Poecilini (Caraboidea, Pterostichidae) de la Península Ibérica I. El género Orthomus Chaudoir, 1838 // Nouv. Rev. Ent. (nouvelle série). Vol.13. No.3. P.261-274.

Pupier R. 2005. Contribution au Catalogue des Coléoptères Carabiques d'Algérie // Cahiers Sci. Vol.9. P.65-78.

Pupier R., Coulon J. 2013. Étude des organes génitaux des femelles et considérations sur la taxonomie de deux groupes d'Orthomus

\section{Appendix. Material examined}

Acronyms of Spanish provinces are: Aragón (Huesca HU, Zaragoza Z, Teruel T); La Rioja (Logroño LO); Galicia (Orense OR); Islas Baleares (IB); Valencia (Valencia V, Alicante A); Castilla-La Mancha (Guadalajara GU, Cuenca CU, Toledo TO, Albacete AB, Ciudad Real CR); Madrid (M); Castilla-León (Soria SO, Segovia SG, Zamora ZA, Ávila AV, Salamanca SA); Murcia (MU); Andalucía (Almería AL, Jaén J, Córdoba CO, Sevilla SE, Huelva H, Granada GR, Málaga MA, Cádiz CA).

1. Collection of the Department of Zoology and Physicial Anthropology, University of Murcia. All captures were carried out by members of the Department, labelled DZAFMU, if not stated otherwise.

Orthomus abacoides

Algeria: $2 \sigma^{7} \sigma^{7}, 3$ 우, Froha, Ntnl Rd. 6, 26/5/2010; reservoir El

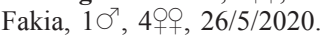

Orthomus balearicus

Balearic Islands: $1+$, Mallorca, cova de Cal Pesso, Pollensa, 12/12/2009.

Orthomus barbarus barbarus

Spain: 512 exx collected in the provinces of A, AB, AL, CR,

CU, GR, GU, J, M, MU, TO, V, from 1975 to 2021.

Orthomus berytensis

Canary Islands: (TF, GC): TF, 8 localities, $24 \sigma^{7} \sigma^{7}, 3290$ 9/2 2000 and 17/1/2007. GC: $20 \sigma^{\top} \sigma^{7}, 30+9,6$ localities, 10/2/2000 and 16/1/2007. Morocco: $5 \sigma^{7} \sigma^{7}$, 2कo, Assilah, 29/5/2007. Algeria: $3 \sigma^{7} \sigma^{7}, 4$, 9 , El Malah, Natnl Rd 22, 25/5/2010; $1 \sigma^{7}$, col de Zarifette, 22, 25/5/2010; $3 \sigma^{7} \sigma^{7}, 2$, 9 , Modzbah + 6, 26/5/2010; $1 \sigma^{7}, 8 \mathrm{~km} \mathrm{NO}$ of Aine Tedeles, 25/5/2010; $1 \sigma^{\top}$, Gdyel 26/5/2010; $2 \sigma^{\top} \sigma^{\top}$, Oran, stream besides $+2,26 / 5 / 2010$.

Orthomus dimorphus antoinei

Morocco: 10', Ouaoumana, $20 \mathrm{~km} \mathrm{~S}$ of Khénifra, 17/2/1999; $1 \sigma^{7}$, road Tadla-Khénifra, km 20, 17/2/1999; $1 \sigma^{\top}$, Koriffia River, 17/2/1999; $2 \sigma^{\top} \sigma^{\top}, 2$, 90 , Skhirat Plage, Rabat, 22/10/2004; $3 \sigma^{\top} \sigma^{\top}$, 2 우, Kasba Bouläouane, 12/12/2007; $5 \sigma^{\top} \sigma^{\top}, 3$, $9+, 10$ km N Mohammedia, $1 / 6 / 2007 ; 10^{7}, 1$, Loulad, road to phosphates, $31 / 5 / 2007$ $1 \sigma^{\top}, 1$ 옹, Oulad Frej, 13/12/2007.

Orthomus formenterrae

Balearic Islands: $4 \bigcirc^{7} \sigma^{7}, 5+9$, Sa Caleta (Ibiza) 30/2/1976 JS col.; $2 \sigma^{7} \sigma^{7}, 2$, 2 , Formentera, 23/2/2000; $3 \sigma^{7} \sigma^{7}, 700$, Formentera, 12/5/2010; $5 \sigma^{7} \sigma^{7}, 5$ 우, Sa Negreta, Ibiza, 12/5/2010.

Orthomus hispanicus

Portugal: $1 \sigma^{\top}$, Nave de S. Antonio, serra da Estrela (PT) 1600 m, 15/6/1982 JP Zaballos col.; $2 \sigma^{\top} \sigma^{\top} 2$ 2 +9 , Serra da Estrela (PT), km
Chaudoir hispano-maghrébins (Coleoptera, Harpalidae, Pterostichini) // Bull. mens. Soc. linn. Lyon. Vol.82. Nos 9-10. P.215-228. Serrano J. 2003. Catálogo de los Carabidae (Coleoptera) de la Península Ibérica. Monografías de la Sociedad Entomológica Aragonesa, Zaragoza. Vol.9. 130 pp.

Serrano J. 2013. New catalogue of the family Carabidae of the Iberian Peninsula (Coleoptera). Ediciones de la Universidad de Murcia. 192 pp.

Serrano J. 2020. Catálogo electrónico de los Cicindelidae y Carabidae de la Península Ibérica (Coleoptera, Caraboidea). [Versión 12-2020]. Monografías electrónicas SEA. Vol.9. http:// sea-entomologia.org/monoelec.html

Serrano J., Guerrero J.J., Fernández B., Ruiz C., Petitpierre E. 2015. Los coleópteros carábidos de las islas Baleares (Coleoptera: Carabidae) // Boln. Asoc. esp. Ent. Vol.39. Nos 1-2. P.39-97.

Wrase D.W., Jeanne C. 2005. Synopsis of the Orthomus rubicundus group with description of two new species and a new subspecies from Morocco and Algeria (Coleoptera, Carabidae, Pterostichini) // Linzer biol. Beitr. Vol.37. No.1. P.875-898.

Zaballos J.P., Jeanne C. 1994. Nuevo catálogo de los carábidos (Coleoptera) de la Península Ibérica // Monografías de la Sociedad Entomológica Aragonesa, Zaragoza. Vol.1. 159 pp.

7 road 18/1; 22/10/1990. Spain: $1 \sigma^{\top} 2$ 2o, Pto. de Monteviejo (León) 18/10/1988; $9 \sigma^{7} \sigma^{7}, 5$ 우 Laguna de los Peces (ZA) 20/10/ 1990; $3 \sigma^{\top} \sigma^{\top}$, Cabeza Manzaneda (OR), 9/19/1999; $10^{\gamma}$, 1 , , sierra de Larouco (OR), 2/11/2006.

Orthomus lacouri pupieri

Algeria: 5ㅇ, reservoir El Fakia, 26/05/2010.

Orthomus maroccanus

Spain: $4 \sigma^{7} \sigma^{\top}, 3$, + , Tarifa (CA) 5/1/1989 JS col.; $3 \sigma^{7} \sigma^{7}$ idem 7/ 12/1988; $10^{7} 1$ 오, S. Roque (CA) 20/1/1990; 1으, Betis (CA), 2/4/ 2010; $1 \sigma^{7}, 2$ 우, Puerto del Cabrito, Tarifa (CA), 30/5/2006. Morocco: $1 \sigma^{\top}$, Tetuán, 16/2/1999; $4 \sigma^{\top} \sigma^{7}, 4$, $90,5 \mathrm{~km} \mathrm{~W}$ of Bab Berret, forest track, 19/10/2004; $3 \sigma^{\top} \sigma^{7}, 3 \circ 0$, road Ceuta-Tánger, 18/10/ 2004; $1 \sigma^{\top}, 1$, , Tanger airport, 20/10/2004; $18 \sigma^{\top} \sigma^{\top}$, 1990, Mulay Abdessalam, 29/5/2007; $2 \sigma^{7} \sigma^{7}, 290,4 \mathrm{~km} \mathrm{~S}$ of Bab Taza road to Chefchauen, 28/05/2007; 10', 1웅. Tidiquin, Rif Mt, 21/10/2004. Orthomus perezii

Spain: $10^{7}$ Griegos (TE) 15/7/1981 JS col.; 1 \% Ledrada (SA) 17/1/1982 JP Zaballos col.; $2 \sigma^{\top} \sigma^{\top}, 2$, 2 , , sierra de Pela (Campisábalo, GU), 23/06/2000.

Orthomus tazekensis rifensis

Morocco: $1 \sigma^{7}, 6$ 우, road Chefchauen- Ketama near Bab Taza,

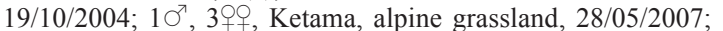
$3 \sigma^{7} \sigma^{\top}, 2+$, Tidiquin, Rif Mt., 20/10/2004; $4 \sigma^{7} \sigma^{\top}, 2+\circ$, Ketama, 28/5/2007.

Orthomus velocissimus akbensis

Spain: 290 , Aznalcázar (SE), 26/10/1977, A. de los Santos col.; $10^{7} 1$ 우, idem 20/2/1982; $10^{7}$, PN de Doñana (HU), 5/12/1977 C. Montes col.; $1 \mathrm{O}^{\top}, 1$, , sierra Gorda, Loja (GR), 22/5/2005; 1 , sierra

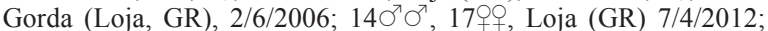
7 우, Casarabonela (MA), 25/4/2000; $10^{7}, 1+$, El Torcal, Antequera (MA), 20/3/2004; 2कㅇ, Parque Regional Subbética, 5/12/2006; 1 , El Arahal (SE), 7/4/2021; $2 \sigma^{7} \sigma^{\top}, 2$, 9 , Osuna (SE), 7/4/2012; $3 \sigma^{7} \sigma^{7}$, 2 우, Cabra (CO), 15/4/2014.

Orthomus velocissimus pardoi

Spain: 4우, Mijas (MA), 25/7/1977 JS col.; $10^{7} 1$ 1우 Coín (MA) 24/8/1977, JS col.; $5 \sigma^{\top} \sigma^{\top}, 3$, 3 , idem, 24/12/1979; $5 \sigma^{\top} \sigma^{\top} 1$ 1 우, Pto. del Viento, Ronda (MA), 22/4/1979 JS col; $10^{7}$, idem, 2/4/1994 JS col.; $1 \sigma^{\top}, 2$, + , sierra de las Nieves, Tolox (MA) 4/4/1983 JS col.; $1 \sigma^{7}$, S. Roque (CA), 6/12/1988; $1 \sigma^{7}$, idem, 20/1/1990; $3 \sigma^{7} \sigma^{7}, 3$ 우 Tarifa (CA), 7/12/1988; $2 \sigma^{\top} \sigma^{\top}, 2$, 2o+, sierra de las Nieves, Tolox (MA), 4/4/1999; 1, El Burgo (MA), 5/11/2003; 10', 4우, San Pedro Alcántara, road 397, km 17, 17/10/2004; 10', S. Pedro Alcántara, río Verde, 30/4/2011; $10^{7}$, 3우, Igualeja (MA), 17/10/ 2004; $10^{2}$, Benahavís (MA) 30/4/2011.

Orthomus velocissimus velocissimus

Spain: $1+$, salinas de Puerto Real (CA), 27/4/2011; $1 \sigma^{\top}, 1$, salinas de S. Fernando (CA), 26/4/2011 


\section{Collection of the Museo Nacional de Ciencias Natu- rales, Madrid (MNCN).}

I have checked all material of the genus deposited in this institution. A great part of the collection was already studied by Mateu, who published lists of taxa and data of localities, number of individuals, dates and collectors. These data are found in Mateu [1954a, 1955, 1957] and will not be repeated here. In the following it is listed new Iberian material deposited after Mateu's review, and material from Morocco and West Algeria that form part of the present study. Except for a few captures, most individuals from Morocco were collected by Manuel Escalera (abbreviated ME), Fernando Escalera (FE), José Arias (JR) and Cándido Bolívar (CB).

Iberian Material:

Orthomus aubryi

$10^{7}$, Moncayo ,Ag, no more data; $1 \sigma^{7}$, Urbina, O. Soriano.

Orthomus hispanicus

Spàin: $1 \sigma^{7}, 1$, Picos de Europa, no more data; 18 exx, Grado

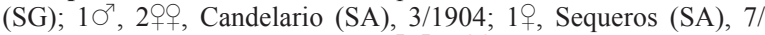

1944, Instit. Esp. Entomología; $2 \sigma^{\top} \sigma^{\top}, 2+0$, , col. Pérez-Arcas. Portugal: $1 \sigma^{7}$, Braga; $1 \mathrm{~m}$, Coimbra.

Orthomus penibeticus

$10^{7}$, Almería (possibly near Adra), Lauffer; $1 \sigma^{7}$, Las Alpujarras

(GR), 17/4/1981, De los Mozos.

Orthomus perezii

$10^{7}$, Menga (AV), 5/1903, Lauffer?

Orthomus planidorsis

$10^{7}$, Lerida (Pyrenees), Lauffer.

Orthomus velocissimus akbensis

1 , , Santa Cruz (SE); $10^{\top}$, Sevilla; $1 \sigma^{\top}, 1$, , La Palma (SE); $1 \sigma^{\top}$,

Rivera de Huelva (SE), 4/11/1998, C. Albaladejo.

Orthomus velocissimus pardoi

$10^{7}, 2$, 9 , sierra de las Nieves, Tolox (MA), 6/4/1982, JS col.

10', 1ㅇ, Río Alaminos, Coín (MA), 24/7/1977 JS col; Parador del Juanar, Ojén (MA), 18/2/1982, Ramírez.

Orthomus velocissimus velocissimus

$10^{7}$, Puerto de Santa María (CA), 2/1894, Sánchez-Navarro.

Maghrebian material:

Orthomus abacoides

$1 \bigcirc$, Sebdou (Algeria) and $10^{7}$ from Oran (Algeria), labelled as

O. barbarus.
Orthomus maroccanus

Morocco: 59+ 2 exx, Beni Msuar, Tanger, ME; 62 exx, Tanger, II-1914, ME; 2 exx, Tánger, 1897, ME; 2 exx, Tanger, XII-1912, CB; 2 exx, Tetuán, ME; 1 ex, Ceuta, ME; 4 exx, Ceuta, 9/10/1929, García Mesave col.; 2 exx, Xauen, VI-1930, CB; 3 exx, Bab Ruadi Beni Siyyei, VI-1932, CB; 5 exx, Bab Taza, El Ajmas, Yebala, VI1930, CB; 13 exx, Larache, ME; 1 ex, Tetuán; 1 ex, 2 exx, L’Hadjeb, 19.4.1927, ME; 4 exx, Dar Riffien [=Kud. Federico], ME; 2 ex, Djebel Musa, ME; 1 ex, Benzú, ME; 1 ex, Hacho, Ceuta, ME; 18 exx, Tanger, ME; 4 exx, Biut, ME; 1 ex, Alcazarquivir, ME.

Orthomus berytensis

Morocco: 21 exx, Sus, ME; 13 exx, Sus, Agadir, ME; 3 ex, Aglú (Sus) ME; 2 exx, Tarudant, IV-1912, ME; 2 exx, Hamed.-UMalk, IV-1912; Kureimat, 4-1912, ME; 3 exx, Essaouira [=Mogador], ME; 23 exx, Tazila (Ifni), I-1935. FE; 18 exx Adai (Ifni), I1935 FE; 2 exx Tiliuin (Ifni), I-1935, FE; 2 exx Tagragra, 1.7.1934 FE; 1 ex Ugug (Ifni), XII-1934, FE; 1 ex, Gulimin Valle del Nun, I1935, FE; 2 exx Asif Ibudrar (Ifni), I-1935, FE; 3 exx, Yebel Tamarrut (Ifni), I-1935, FE; 7 exx, Amasin (Ifni), I-1935, FE; 5 exx Sidi Ifni, XII-1934, FE; 2 exx, Tánger, CB; 31 exx, Ain Aguisgal (Ifni), I-1935, FE; 96 exx, Nfis, VII-1907, ME; 1 ex, Ouad Batls, ME; 1 ex, Marruecos, Amismiz (Atlas), ME.

Orthomus dimorphus antoinei

Morocco: 2 exx, Aglú (Sus), ME; 1 ex, Casablanca, 1898, ME; 1 ex, Mskala, ME; 5 exx, Meknes, IV-1925. ME; 4 exx, Casablanca, ME; 13 exx, Sus, Agadir, ME; 2 ex, El Hadjed, Marruecos, 16-41925; Volubilis, ME; 2 exx, Volubilis, V-1925, ME.

Orthomus lacouri kocheri

Morocco. 83 exx, Cabo del Agua, Melilla, XI-1908, JR; 1 ex, Cabo de Agua (Melilla), XI-1908. JA; 26 exx Restinga, Melilla, XI1908, JR; 53+ 1 exx, Melilla, XI-1908, JA; 2 exx, Melilla, XII-1909, JA; 1 ex, Melilla, V-1933. Pardo Alcaide; 5 exx, Cabo de Agua (Melilla), XI-1908, JA; 54 exx Río Muluya, XI-1908, JR; 1 ex, Río Muluya (Melilla), XI-1908, JA; 4 exx, Melilla, CB; 1 f, Melilla, Carlos Pau col.

Orthomus leprieuri

Algeria: 2 exx, Schramm. In the collection it was labelled as $O$. hispanicus from La Sagra (GR), surely a wrong labelling of the individuals.

Orthomus tazekensis rifensis

Morocco: 1 ex, Tidiquin Ketama, Rif, VI-1930, CB; 1 ex, Tainza, Ketama, Rif, VI-1932, CB; 1 ex, Tizi Taka, Beni Seddat, Rif, VI-1932, CB. 